\title{
Accounting Theories, Financialization Process and Neoliberalism
}

\section{Slaheddine Yagoubi}

Faculty of Economic Sciences and Management, University of Sousse, Tunisia.

*Corresponding author: Yagoubi Slaheddine, Faculty of Economic Sciences and Management, University of Sousse, Tunisia. Tel: +216-24-141-479; E-mail: syslahedinne@gmail.com

Rec Date: May 1, 2014; Acc Date: Jul 21, 2014; Pub Date: Jul 28, 2014

Copyright: ( 2014 Yagoubi S. This is an open-access article distributed under the terms of the Creative Commons Attribution License, which permits unrestricted use, distribution, and reproduction in any medium, provided the original author and source are credited.

\begin{abstract}
The accounting standards pervasiveness, in coexistence with the earliest civilizations, argues the accounting social dimension as a rule that governs relations between individuals. Therefore, accounting techniques as social norms and kind reflection vector describe the society conventions and principles. This societal reflects made it more complex and esoteric. Accounting seems a buildings assortment, historically dated and generating economic effects as a mechanism for tracking and remote monitoring the economic activity evolution. Accounting science is rooted, it is no longer neutral. In this sense, it would be more a gradually building steeped in cultural influences, social conflict and political issues and choices. Given the economic activities complexity and the interest deregulation, accounting sciences remain as an analysis tool for major conflicts, differences, and each party opportunistic concerns. A management tool for vertical relationships, guided by personal preferences and attitudes which each consider meditation to increase its profit margin and its timeliness. In this environment, information has become the success secret and a profit source.
\end{abstract}

Keywords: Accounting theories; Financialisation; Neoliberalism; Financial stability; Regulation

\section{Introduction}

The defining features of the accounting approach include (a) recognition of the circular flow of goods and money in the economy and the balance-sheet identities implied, (b) a separate representation of stocks (inventories, wealth and debt) and flows (of goods, services and financial funds), (c) explicit modeling of the financial sector as distinct from the real economy, so allowing for independent growth and contraction effects from finance on the economy, (d) nonoptimizing behavior by economic agents in an environment of uncertainty, and (e) accounting identities (not the equilibrium concept) as determinants of model outcomes in response to shocks in the environment or in policy[1]

It follows, accounting faces three challenges. Extra accounting indicators management reconciliation with a dissemination shorter periodicity, directly affect the measurements activity and their perspectives. To this is added the technological innovation and the new practices development (stock options, pension background: financial derivatives) which induce a radical change in real and financial economic conditions. Another dilemma is added to a bad adaptation of potential changes in concepts corporate life reassessment (goodwill, merger). Further the intangible costs development and accounting data implementation between national accounting systems was aggravate the defaults. Legitimate, accounting sciences are governed to provide reliable and relevant information, to meet the expectations and stakeholders needs, consistent in their time dimension, and comparable company to another. These practices have evolved into a social spirit administered by agency costs postulated by the contractual relations between owners and managers relations.

The accounting function has evolved bypass expectations and increased reflection of power relations and interest requirements conflict. Financial globalization and the base regulation, globalization and integration of the entire financial sector, are causing multiple renewals and diversification constraints facing businesses. These circumstances legality development challenges facing legislators and experts equally. The financing activities interconnection and complexity have included major complications away from the accounting texts inadequacy. This requires the accounting system's designer interventions to address its shortcomings. The intangible economy rises (based on new information technologies and communication) was controversial, full, traditional conditions of production factors such as labor and capital. The new business climate emergence, including information unanimous, accounting is seen as an adequate firms representation and their transactions. However, an accurate accounting representation of business performance true picture is naive.

\section{Accounting Standards History}

\section{Accounting functions and accounting regulations: Marxian foundations}

Different accounting patterns of behavior can be identified which are the outcomes of many years of development influenced by factors such as cultural values, legal systems, political orientations, and economic development. The challenge now is to adapt what has served well in the past to the new global imperatives of transparency and credibility of accounting in order to facilitate efficient flows of capital to the world's financial markets. To do this requires recognition that tradition and culture shape accounting thought in a country and that change is more likely achieved when it is truly informed by an understanding of that country's heritage. International Accounting Patterns, Culture, and Development [2].

The accounting history seems to imply two focal points. On the one hand, the accounting essential nature is the measurement function, 
which includes accounting as an evaluation system. Its second role is institutional, which includes the legal framework and the accounts settlement process. To develop the accounting discipline as a social science, theoretically, we should integrate these two focal points in solving fundamental problems, such as accounting's function and finality. To do so, we focus on two accounting core functions according to Marx. Thus, the accounting regulation function is the identification and control of the economic process and the other is mediation function who transforms the economic value.

This mediating role was never addressed by previous research Takashi Oguri [3]. This is a central function for the accounting actual activities analysis and various contemporary issues of accounts investigation. Consequently, this helps to explain the accounting's institutional aspect genesis and its ideological function. Thus, accounting regulation can be divided into two types, namely, the micro accounting and macro regulation. The macro-accounting regulation now leads to what could be the macro-accounting worldwide. Should internationally, develop theories and alternative strategies to constrain capitalism violent symptoms [4].

These potential changes and accounting control system were accompanied by the strengthening of the accounting information role and its relevance to the economic expert's analysis. Faced with new forms of opacity and dissemination responsibilities, the information provided by the leaders remains questionable. The solutions remain inoperative. The control forms, strengthening prudential supervision and new laws on financial security, accomplished the financial stability illusion. The problem is informational. In an investment environment strongly accentuated in the financial markets, and with the rise of the speculative spirit in a capital economy, information is at the heart of any analysis form. At some point, the IASC, and without a warrant anyone could win solutions to problems encountered in this decade.

Driven by its heritage independence and technocratic organization effective, standard-setters in the IASC landscaped essential solutions. Analysis developed by the Anglo-Saxon framework adaptation that advances a controversial value concept interpretation from the company financial economy, the speculation is that the evaluation is calculated, in the company, which is the estimated fundamental value. It appears that the opposition between these two measures is qualitative. It deals with how to develop the forecast, the type of information that is used to anticipate the price is formed by the speculator from the market observation, and anticipation came from observation of nature [5]. These changes have been the cornerstone in accounting policies $[6,7]$.

The real conceptual change failure in the production and accounting information dissemination process has pushed setters to emerge to fair value as a convention assuming beliefs and shared considerations are more increasingly convergent. Decisions making trumps accountability and control function. The objectives reorientation to the users needs looking for information. Efforts are being made to develop more relevant information and reliable; the information degree it's to the usefulness criterion. Thus, the speculative behavior drives futures setters' plans to face more complex financial instruments, excessive volatility and different risk types incurred. These failures marked the financial institutions in the United States in the eighties of the last century and are immune from questioning standard accounting models. These concerns have revealed the shortcomings and the historical cost model limitations [8].
Originally providing timely and relevant information and the derivatives role development as difficult to handle financial instruments, have now limited the historical cost [9-11]. The preventing financial crises policy, which are transformed into penalty time in systematic and systemic crises in other cases as a contagion result, and a relevant informational volume desire, are at the fair value adaptation origin. These fair value stabilizing roles are added to the security function and the uncertainty minimization.

The multiples analysis's forms and theories were originally the relevance of accounting information testament. Recently many attempts have emerged in the attitude of expressing the current financial crisis as a result of model "fair value". The results have limited the involvement of fair value in the crisis. Laux and Leuz [8] studied the fair value contribution in the current financial crisis and conclude a weak dependence between the banking crisis and fair value accounting. This contradicts the beliefs that say that the current crisis is due in large part to the new accounting standards impact.

\section{Accounting's discipline emergence}

In macroeconomic model, accounting is closely correlated with national economic policies. The accounting discipline could be smoothed to promote economic and financial stability, impairment assessment is adjusted to stimulate growth; special reserves are created to promote investment. Thus, accounting is included to overcome the macroeconomic concerns and minimize the risk while reducing uncertainty. In the microeconomic model, accounting is drawn as a business economy branch. In this model, there is a fundamental orientation towards individual economic entities. Furthermore, accounting concepts are derived from economic analysis, making a fundamental accounting concept that deals with the real monetary capital terms maintenance invested in the company. In a separate discipline; accounting is scanned as a service function derived from commercial practice. A rooted respect for pragmatism and judgment is included. Accounting is considered able to develop its own conceptual framework, derived on the basis of its own successful social practices. Income is a pragmatic measure that seems useful in practice. Revelation, complete and accurate, is "acceptance of explanatory principles" that has evolved over time.

In the standard model, accounting is scrutinized as an effective administration control tools. However, an accountant, more scientific approach is adopted. This vision provides a uniform approach to measurement, disclosure and presentation, easy to use. Accounting is a control way for all businesses, used by all types of experts, including managers, government, tax authorities and centralized economy with planned manner, and the other countries heavily involved in economic planning. While accounting was considered a academic discipline in universities for more than a century, the question of whether the accounting is an art or a science, has long been raised, and still again, by researchers in various disciplines [12-15] tried to determine accounting vis-à-vis art and science. In general, arts depend from personal interpretations individuals' position while the sciences tend to require a high level of agreement among practitioners about observable and measurable phenomena. Sterling said that accounting, as currently practiced, was closer to art than science. In this sense, the accounting should move towards a scientific approach to produce rigorous measurement procedures whose results are economically significant. Sterling expected that accounting would be a science in itself as economics and other social sciences. In addition, its definition as a scientific approach focused on the formation of asset's evaluation 
theory that could include economic events and econometrics methods. Indeed, the theoretical framework provided by economics, has often been used to analyze the accounting controversies, and was instrumental in the development of the conceptual framework and some reports of financial accounting rules.

Stamp [16] for its part, is expressed on the subject, advocating a theoretical definition of the accounting discipline similar to the law process as opposed to the Sterling' scientific direction. In Stamp accounting perception, judgment play a stronger role in the accounting practice construction in which different accounting methods could be used. From the point of view of this legal approach, the accounting would be largely affected by the human element and must develop an institutional structure for the legitimacy of his judgment and reconciliation with conflicting interests. Stamp legal's approach suggested that accounting discipline is closely related to law theories, political or sociological science concerned with the analysis of accounting as a social institution. If we should asked a fundamental question of "what is accounting?" in to address its essential nature, we should examine the various approaches elements proposed by authors such as Sterling and Stamp. In light of their arguments, it seems that accounting involves at least two focal points and several disciplines. The disciplines include economy, law, political science, sociology and other social sciences.

\section{Accounting: social conflicts' analysis tools}

From purely practical point of view the reconciliation between economic theory and both macro and micro accounting may come about to a great extent by the growth in sophistication of the economic agents who understand that the three are a great fortunes to be made in arbitrages between accounting and legal conventions which do not match the underlying economic realities sufficiently closely [17].

Accounting's social dimension remains attached to the individual contingencies and influenced by the thought that dominates manager's strategies. Conventions and rules remain as a combination of each country's specificities in each period. The development shift, the openness degree and economies integration within the sphere of the global economy, means that accounting standards provide specific solutions to a given time and sometimes be changed according to the political powers and financial conglomerates interests.

Accounting sciences, to that extent, remains as a mix differentiated requirements of the various parties to the extent of inventing common standards for cross concerns. Anglo-Saxon directions emphasize the supremacy of economic substance in search of the legal validity of the texts. At the other tins, European economies aimed at heritage strongly influenced by legal texts' knowledge. Texts Knowledge gives priority to interests' famous protection of various parties and maintains a more appropriate prudential management.

To this, the actual account tries to reveal the set of actions relating to the productive systems of financial reporting. The accounting informational role is measured by the suitability degree of various production techniques, legal rules and the economic environment of each party. Internally, accounting information meets the requirements of leaders who want to drive value and the results of their businesses and have a preventive framework to cushion any disputes with stakeholders. In externally way, financial reporting provides relevant information to extract a reliable representation the transactions and risks values.
The information system is governed by various stakeholders, issuer's legislation, practitioners (officers), adding listeners who give a certificate to guarantee the credibility of the accounts and the reliability of the information provided to markets. Auditor competence and probity are presumed and dependent on their adequacy to legislation issued by the standard setters. The classification of various business activities cannot be presumed in the writing of accounts assets and liabilities. The depreciation operations, impairment of inventories are as examples phenomena requiring attribution values for estimating and anticipating their future values.

Colasse prove that "Accounting Standards is not empty and hardly presents a process of self" Forms of standardization may, depending on the country, based on different actors (state, accounting profession, independent...) gives rise to various combinations that define significant "standard forms". Thus, regulate countries' balances sheet in short periods and more generally for several decades, need many factors determine the national heritage of each standardization type (economic system, legal tradition, and culture of the business world, level of development, organization and competence of the accounting profession...). The process itself is subject to social issues and therefore power relations that lead to trade-offs and compromises between actors [18-20].

Upon his origin, accounting had several dimensions and functions. As a social science that governs the contractual relations which are derived from agency between principal-agent theory. In this regard, the accounting information is entered as a means of control and surveillance. The gap between modern accounting theory and practice and economic theory is large and to a great extent exists because the need to reconcile the two was less important in simpler economics. The reconciliation must come from both ends, like the digging of a major tunnel. In this note only economist's responsibility is stressed [17].

Potential changes in the international financial markets and simultaneous crises makes financial information provides credible representations of companies health status beyond the barriers preventing published by managers to maintain the "internal kitchen" of their companies. Henceforth, accounting information faces two pillars which provide greater transparency about the state of the company (efficiency of information), in the other hand, it allows to arrange a relative opacity, dissimilation of secrecy and hence bring to leaders a manipulative flexibility. Accounting information is then faced with a challenge "transparency-secret." Attempts to improve accounting standards emerge in a direction to bring more transparency to face manager's opportunistic behavior in order to achieve an efficient security of financial markets.

The tradition's shareholding rise, governance and lack of control on the part of shareholders, have made the transparency of the accounting function a priority. The insertion of the positive agency theory (shareholder theory) reflects in [21] advance the firm as a nexus of contractors led by a manager. Such a way that agency cost's mitigation impairment trained by the divergence of parties interests engaged, by the speculative behavior beyond attempts to search for innovation, make implementation of promising projects and the development of long-term investments [22,23].

The concept value's dominance and the equipment investment design, sometimes, causes fraudulent practices characterized by the rise of speculative mind at the expense of social business functions. Faced with this speculative madness and looking for a flexible 
handling, often at the limit of lawful or unlawful, standard setters have adopted an innovative behavior. A change existing agreements and the introduction of new concepts [24] promoting the flow of sufficient liquidity in response to the way planning policies financialisation of the economy.

In this regard, the speculative financial' mind (financial capital) outweighs the classic entrepreneurial logic, market introversion above company extraversion. Looking for a short-term capital income and achieving instant income, innovation and decreed the creation in appropriate development's model. This radical change in the opportunistic behavior did not allow the information to be the capitalistic economy's secret. Classical's production function gives room for shareholder spirit based on speculation that the changes in value of financial assets are analysis tools for managers and not the operational performance of the company [25]. As for Keynes, the immobility of capital is given a concrete, objective, liquidity, in turn, is an artifact. Accounting standards that appear as liberal policies' cicerone have made the formation of value, profit and its distribution more questionable. Shareholder value dominates the market value.

The contractual model $[26,27]$, monistic shareholder, is calibrated to match as Anglo-Saxon corporate governance's conception. However, the companies' social role and their contributions to sustainable development in the act of research and innovation were diverted to institutional and partnership design that draft to the concentration and strengthening the conglomeration. This cleavage in the status and function of companies, made the analysis in terms of information more clear. The information, such as financial reporting tool, requires more attention as a tool for development and anticipation of future changes, an apologetic market representation, guarantee justice and the common good $[28,29]$. The social reporting role is biased and hindered or nullified with unanimous information provided from speculative financial reporting.

The rising inflation in liberal economies during the seventh decade last' century was at the origin of adaptation assessment based on historical cost models. The Western economy model distortion due to the continuous rise in prices, the Anglo-Saxon standard setters have defended a historical cost model derived from the loss of purchasing power of money. However, attempts to improve the information content of measures based on historical cost could not be empirically significant. These experiments have sketched on a cost borne by businesses to produce information in current value in addition to subjectivity in the behavior of listeners.

Mitigating discretion of managers and the fight against shaping accounting results are among the solutions against a subjective assessment of the risks, the likely costs and falling prices of assets (impairment of assets over). However, the fair value introduced convergent designs conflicts and manipulations as Garmilis shows the adaptation of standards using fair value is always made in terms of conflict between regulators and standard setters on one side and companies on the other side. It goes without saying that the concerns of the various stakeholders (analysts, lawyers, regulators and legislators) were to develop accounting standards that provide an accurate picture of the companies' health to market stability. Many methods are developed, different standards are applied, but the effort to ensure efficient information continues. Efforts are focused to provide accurate financial information and the smooth flow of reliable and non-manipulated data.
Abundant qualitative and quantitative research has developed [30-32]. Econometric models have attempted to reduce the gap assessment and maintain market stability. Several mechanisms are used and different studies were conducted. The information provided by the accounting remains an important tool for analysis. The greater sensitivity of balance sheets to market fluctuations induced by the accounting information is obviously not without impact on the financial markets volatility. Indeed, this same information is processed at different angles. Financial reporting accumulates as good news, the prudential regulator in a more critical ample, and as a source of risk assessment for the rating agencies.

Indeed, studying the financial markets volatility in terms of new accounting standards appears interesting. Various theories have been developed and have been a fertile field for studying and analyzing accounting's information as a pillar of financial capitalism and defend its principles based on speculative profit and opportunism preference to a more profitable value in terms of risk mitigation.

The accounting regulation is defined as the process of creating (or processing) accounting rules, however, regardless of institutional conditioning. In its Social volume control is the act of production and dissemination of accounting information, arbitration of disputes and diverse interests of different stakeholders frame. An economic perspective is additional to the different currents that have studied and analyzed the financial reporting. Each current is specific to a singular vision of the phenomenon.

\section{Social and accounting economic dimensions}

Micro accounting model: The modern finance ambivalence, have broadly involved in the recurring debates from the accounting's role in the recent crises across micro empirical works developed to study the financial and economic implications of accounting models. Amplifier and accelerator effect of the crisis worsen the panic' rate, and the cyclical role of accounting discipline and the contagion transmission, remain ambiguous. In this regard, two points of view have proved controversial. In economic sphere without financial frictions and with complete markets, the flow of funds into productive agents is constrained and therefore the distribution of wealth is not relevant. In the presence of financial frictions, the distribution of wealth may change appropriate to macroeconomic shocks, including an axial accounting function.

A radical change occurred during the seventies with the overabundance of Keynesian's money conception as a simple veil and the interest rate is the only instrument that connects the real economy to the financial sector. This coincides with the abandonment of the ISLM model that gives competitive role to commercial banks, provided their primary role in the capital' allocation and follows the contemporary finance. Thus, the development of the J.B. Say's stock theory precedes Francois Quesnay's advanced flow analysis (eighteenth century). These changes were accompanied with three major developments leading accounting to release its normative conception. In economic design, positive accounting theory approach states that any proposal may not be valid unless it is verified empirically. Second, the model of asset pricing (CAPM), has structured the relationship between accounting information and financial markets. Thus, the efficient market hypothesis $(\mathrm{MCH})$ focuses on accounting information and its overall effect on investor expectations (theory of efficiency, rational expectations model). 
The liquidity preference as advanced in Keynes advanced and the uncertainty surrounding the financial sector and the business world, requiring the minimization of risk and uncertainty relief to support financial stability. The alternative and financing instruments of the economy, have to integrate new methods and sources of supply for economic agents. To this are added innovations in accounting standards and increased liquidity preferences which influence asset price and make them more volatile with excessive manner.

Macro accounting model: Recently, we note the rise of new postKeynesian wave's macroeconomic models that include finance in the study of investment activity with the process of credit rationing and growth models [33]. These models are based on the balance sheets (balance of payments), firms and banks to assess the profitability of the investment and the level of indebtedness of firms (Tobin's Q). Thus, accounting seems to have abandoned its static role as a tool for measuring and calculating a scientific approach with dynamic character. There is a new conception of accounting discipline as a source of reliable and relevant information to enable greater transparency expectations (rational anticipation models). The accounting policies have become a common knowledge (theory of conventions) to which the contract relates, shareholders, bankers,... The reformulation of the assumption of financial instability, with a purely systemic and dynamic financial analysis based on aggregation of the free play of individual behavior as a fragility stimulator of a deregulated financial sector remains axial.

Our effort extends to discuss different ways of identification, classification and development of the accounting discipline as a tool for both economic, social and source of financial information on the international scale. This refers to examine key theories that have served the emergence of accounting and how they influence the behavior of financial markets.

The institutional approach emphasizes the economic process involves the social structure including the state, the firm, laws and culture. In this approach, accounting is considered one of the social institutions that play an important role in forms, rules, laws and accounting bodies. Thus, the accounting can be considered an appropriate existence within the economic process. The problem of the institutional approach is how to explain the genesis of the institution employing the economics logic. This approach extends the traditional Veblenian school for new schools with economic transaction costs, contract theory and comparative institutional analysis [34]. The advanced of these authors is that of the economic theory of Marx belonged to this approach and offered the best opportunities for the theoretical analysis of the financial institution genesis.

\section{Changes in the Accounting Rules}

Accounting both for macro and microeconomic purpose deals with process and dynamics. Much of the best microeconomic theory has dealt only with statics. General equilibrium theory shows the virtues of a price system, but abstracts from price formation and all of the accounting problems which appear in disequilibrium. An approach is suggested here for reconciliation of accounting with general equilibrium. More generally, it is suggested that the importance of accounting to economic theory has been underestimated [17].

In historical terms, the first step in the development of accounting regulation occurred within the monarchy micro compatible regulation. Under this approach, the accounting is concerned with the coordination of profits distribution among the actuators using the commercial code or the act of the company. It was used to adjust firms and other economic organizations for a long time. The second step, however, the macro-accounting regulation is materialized with the introduction of the legislation values in the United States (1933/1934). While Regulation micro and macro-accounting coexisted as dual regulatory system, the macro-accounting rules became more dominant than micro computable recent years. National capitalist economies are transformed gradually into a capitalist economy, financially integrated in international equity markets, are beginning to require a macroaccounting rules, rather than micro face extending financial markets.

The macro-accounting rules now lead to what might be called the international accounting rules. In the United States, for example, macro-accounting regulation is driven by standards bodies such as safety committees and exchange or referral agencies such as the FASB. An important factor in the $21^{\text {st }}$ century will be the international accounting standards set by the International Accounting Standards Board (IASB) [35], which consists of organizations worldwide reference. In this context, many countries try to introduce harmonized with international standards for their institutions to better integrate into the global system of business accounting standards. The purpose of this transformation will pave the way towards global market share and support the values of international transactions.

It seems that the goal of the U.S. must lead as possible, as many countries, its commitment to the international regulations (macroaccounting), which may reflect the external capital flows and promote the international capitalism development. The functions of the International Rules of the macro-accounting are identical to the accounting institution shown in Figure 3. A major function is to maintain the international economic order and the other is to encourage the accumulation of capital internationally. Today, the function seems to be fortified by the International Regulations advantage of macro-accounting. In other cases, the rules of the international macro-accounting tend to favor the interests of multinational corporations and banks. The shape and the exact function of the International Rules in the macro-accounting level depend on the outcome of the fight against international capitalism and efforts to solve the problems associated with financial globalization, no doubt one of the most significant issues of the $21^{\text {st }}$ century.

Trends in international regulation of macro-accounting influence the activities of the Accounting standards. Macro-micro computable regulation within the state borders will continue to exist under the strong influence of international law. Critical accounting schools have long criticized the accounting regulations and tried to develop forms and alternative methods of settlement. However, now that we are seeing a decline in the regulation of the national accounts for a global macro accounting approach, it is imperative that we reform this payment in full force for the violent manifestations of globalization and to harmonize the functioning of global capitalism. To make the democratic reform of macro-accounting regulations and extension of capitalism, we should strengthen the collaboration between international schools critical accounting jointly developing alternative theories and strategies. This allows us to integrate and develop a new approach accommodated the functioning of the international economic process. The identification of the function of mediation can provide the opportunity to form a new approach, hopefully, the international development of a critical theory of accounting. 


\section{Accounting's essential functions}

In "capital" and other works, Marx had suggested two essential functions of accounting, (naturally, accounting in its era was designed as a discipline, which later developed as a science as we know it today). The economic process identification Function is focused on negotiating the transformation of economic value. The interaction of these two functions leads to the formation of the financial institution. It is important that the identification of the economic process based articulates with the service operation. Control function by definition, serves to check or adjust something using testing or observation. The concept of "control" is originally linked to the "identification", head of the intellectual activities such as observation, recording, calculation and verification: "control" seems to be related to a physical control process, mainly the intellectual regulation. In Marx's definition, the combined identification and control functions are considered first and essential function of accounting. As unity within its circuits, as value in motion, whether in the sphere of production or in either phase of the sphere of circulation, capital exists ideally only in the form of money of account, primarily in the mind of the producer of commodities, the capitalist producers of commodities. This movement is fixed and controlled by bookkeeping, which includes the determination of prices or the calculation of the prices of commodities.

Marx argues that the stock accounts in its original form, had existed as an idea in the mind of the producer, i.e. d., such as product identification. The authors described this movement as fixed and controlled by the accounting. In this sense, capital control and identification functions are down with accounting standards. The production function is symbolically reflected in the imagination. This description means that the operation of reconciliation and delivery of accounting continues to apply smooth if economic conditions change. Bookkeeping, as the ideal synthesis and control of the process, the more Becomes Necessary the more the process assumed at social scale and loses its purely individual character.

This passage shows that accounting tools as a monitoring functions and an ideal synthesis process. Its necessity becomes more important with the emergence and complexity of balance economic elements by adding new products and services. In this regard, a "synthesis ideal" and meaningful, can relate to the identification and definition of new objects.

According to this description, the main accounting function is to control operation performed by identification including registration and calculation. Accounting involves not only the epistemological function, which help in control of the economic process, but his suggestion to another very important function to solve the problem including a theoretical conflict between the control function and the ideological function. The ICM approach tended to insist on a fair and accurate reflection of the economic process in which the size of the control function is precognitive. However, the identification process and control did not, actually, a result of the impartial and correct thinking, but rather on the results, which are handled for capital accumulation or distortion in the distribution of income in order to safeguard the capitalists interests.

According to Marx, accounting is considered a factor in the circulation of merchant capital process is realized and functions as capital only by exclusively serving to mediate the metamorphosis of commodity-capital. That is to say, the principal outstanding is to mediate the product-capital transformation. Therefore, the accounting works ideally as a mediator of the metamorphosis in product-capital relationship. While the production process is a true metamorphosis, the circulation process is a formal metamorphosis. Accounting attempts to negotiate a formal metamorphosis of capital by identifying its movement so negotiate a formal capital metamorphosis for not only the accounting calculation but also involves the accounting reporting correspondence or disclosure. Thus, the process flow includes the transmission of communications, letters, telegrams... The additional definition of the economic mediation process as accounting, itself, and is considered a costly economic source, a cost of purely commercial traffic. Marx notes that capitalists must invest a portion of their capital using an accountant. While neoclassical economics does not recognize the value of the accounting system and do not consider the accounting operations as inevitable economic cost.

From the economics perspective, the capital movement needs accounting operations that identify and control the capital movement. The activity cost accounting is counted as part of the capitalist economic cost incurred. Therefore, the accounting operations contribute to the interest proliferation in negotiating the movement of capital. The mediation function influences the function of identification and control to tweak the impartial and correct thinking. This feature seems to be innovative in the public accounting, very important feature to analyze real business accounting and the various problems of investigating contemporary accounts.

The function of merchant transactions is to discuss the conversion of product-capital money-capital or the money-capital-equity product, In other words, this MCM of the merchant Represents no more than a middleman's function for CM between two manufacturers Marx, ibid. In this context, the description goes to the heart of the problem on the basis of accounting. If we could translate trade costs in business operations, we should understand that accounting as one of the trading operations play the role of the intermediary to negotiate the MCM transformation through declaratory work instead of physical work such as sales or purchase. He says this dual function. In addition to its developing function of the industrial and commercial capital, accounting becomes gradually a condition for the emergence of commercial offices concerned a range of funding and direction.

Marx focuses on the transactions nature which is considered as a technological operation. It is important that the business operations are conducted in the capitalist class interests. In other words, the work of business operations has promoted the capitalists interests.

\section{Mediation function}

In addition to the identification and control functions, accounting has a more important role on the capital movement mediation. Several theoretical advantages of mediation function are advanced. First, we can identify the presence of accounting in the economy in the sense that its function is an inevitable part of the economic process and is counted among the economic costs. While, neoclassical economists ignore: the accounts value as a basic framework, accounting's pointview presence, the process and the movement of capital and labor. Second, we can understand why accounting is not the correct reflection of economic events and why the accounting operations have from time to time; result in the manipulation of reported income or accounting procedures.

Accounting, as part of the capital, plays an important role: to promote the movement of capital and grow the capitalists interests. Measurement theories are altered to develop a measurement method 
that reflects correctly the economic events. As a scientific method to measure such proposed by Sterling, accounting could describe the exact image of the economic purpose.

The ICM accounting' approach argues, also, that the measure should reflect the fully capital movement as discussed by traditional measurement theories. The reason that the capitalists have also wanted to control the capital movement correctly calculated. These shareholder theories, however, could not explain why the actual practices regarding accounting tend to produce arbitrary calculation and reporting rather than the correct reflection. We can explain these outlying accounting emphasizing on its mediating role in the economic process trends. Third, we analyze the reasons behind the institutionalization of accounting and the accounting point view establishment characteristics and its mediating role.

Accounting as a mediator, is required to achieve the capital transformation, promote and preserve the changing economic order. The capital movement was forced to emerge with the economic sphere in the capitalism economic laws. Arbitrary accounting operations, such as the balance sheets presentation, take place in many companies. Capitalism must protect its economic arranging laws and rules. However, accounting, manipulated or distorted, can destroy the economic process that can, in turn, induce critical reactions. The capitalist economy needs an institutional framework such as laws, rules and regulations to prevent economic chaos.

From this advances, we can overcome some weakness in the critical school of accounting approach SS. This approach has a pessimistic assumption, and is, always, the result of the accounting institutionalization and financial reporting and twisted dummy preventing the public from acquiring real accounting information made its ideological character and legitimating function. The accounting institution, however, seems to have two different characteristics. That is to say, legitimate accounting, impartial operations as less impartial, properly using ideological and political pressures. The other character is to promote and retain from time to time, operations accounting to maintain economic order that supports the capital movement. Accounting standards is an institutional set to reflect the complex relationships and social-political conflicts. The accounting institution rule aggressively practices of arbitrary calculation and financial reporting that are idle for social reproduction.

\section{Measurement and institutions}

The accounting research has historically shown a great interest in analyzing its institutional structure, has tended to focus on institutionalized interpretations due to the strong influence of the legal framework which consists of two main laws with different characteristics and goals, i.e. security, law and commercial exchange code [36]. The government and the public sector dominated the accounting scene and commercial code which has been strongly influenced by the accounting practice. In such environment, studies in accounting discipline have naturally developed a legal orientation. The accounting measure was generally understood as double-entry process, involving a recording technique and calculation part. The Commercial Code, as well as other laws and regulations, are built on the accounting traditional logic. Accounting, itself is concerned with the recording operation, measurement, and reconciling the stakeholders various interests. Which process the legal conditions is expected to provide adequate regulation. The accounting mainstream has developed an affinity legal discipline. The relationship between accounting and economics became a theoretical issue in recent years involving both methodological problems as when the accounting identity as a school [34]. It turns out that the accounting academic mainstream focuses on a common concern and how to develop the accounting discipline perspective as a social science.

In this context, two main approaches are important. This that focuses on accounting as a measure, particularly in accounting calculation is known for what is called "individual capital movement" approach (ICM). The other relates to the accounting analysis as an institution, is known for what is called "socio-political superstructure approach"(SS). The ICM approach considers the accounting calculation as the reflection of the individual capital movement is analyzed as a movement component of the entire share capital symbolized by MC-M in the Marx capital. The SS approach, meanwhile, studied accounting as an institution with legal, political and ideological structures created by the capitalism economic base. This is a superstructure/economic framework application based on the Marx materialist theory.

The ICM approach has contributed significantly to the development of a scientific measure. The subtending thought ICM approach shared some common elements with the Max Weber theories. A design which provided for the development of the capitalist economy was conducted and supported by reasonable and symbolized accounting techniques. The ICM approach was successful analyzed the logic of Marx accounting theory based on MCM formulation. This approach offers theoretical perspectives to understand and identifying the relationship between accounting and real economic process. Accordingly, a measurement scientific concept based on economics while traditional accounting is to present, only, practices law and rule interpretations [37]. This idea has been criticized by supporters of the SS approach as ineffective, analyzing critically the accounting actual state and involves manipulated accounting practices.

Unlike ICM approach, SS approach has contributed to the capital accounts critique. This approach argues that leadership inevitably involves in monopoly capitalism, arbitrary and distorted to rationalize unequal economic relations. As part of this superstructure, SS approach attempts to establish an institutionalized accounting as part of the superstructure, which supports the ruling class interests and allows the company legitimate status in the form of law, politics, religion, culture and ideology. This approach was successful analyzing the accounting actual behavior and different accounting practices, providing empirical evidence supporting the dummy reporting a legitimization of capital accumulation, such as reported income deformation, balance sheet adjustment or results Operating. The SS approach, however, has been subject to criticism by MCM approach members. According to these critics groping in the theory of measurement is not continued in spite of its importance in accounting theory and the ideological legitimization of discipline or accounting function, oversimplified as a socio-political superstructure function, without thereby identifying widespread possibility of reforming institutions. Differently, this approach is invaded as accommodation as a pessimistic view of such possibilities.

To develop accounting as a social science, it is easy to reflect on the historical lessons and critical studies. In doing so, we must overcome the weaknesses of both approaches and integrate them to approve a fundamental issues resolution such as accounting purpose and methodology [10]. 


\section{Economic processes and accounting's positioning: the identification function}

The accounting cost function mediation and identification of cost in the economy, leading to regulate the accounting position in the economy. From the neoclassical approach perspective or traditional schools, accounting is outside the economy process Figure 1. Neoclassical economies do not identify the accounts presence as a theoretical framework.

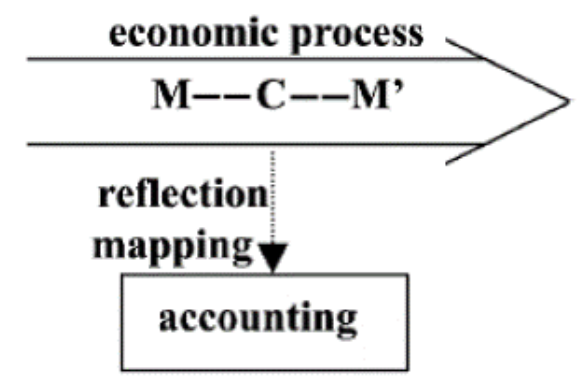

Figure 1: Accounting process outside the economy

Specifically, in the traditional schools opinion, we assume that accounting is a neutral system that reflects, impartially, the economic process and the accounting should make, draw, or copy the object just like a synthetic photo. Accounting is considered one of the management tools, and the relationship between accounting and economics is treated as analogous to the relationship between the tool and the object. This thinking way can be termed as an instrumentalist view of the relationship between accounting and economic processes.

Alternatively, from the Marxist economic perspectives, accounting is located within the economic process as a capital flows component. In Figure 2, accounting exists within the economic process and negotiates the capital metamorphosis. In this way, the claim is that accounting is not a neutral system or an independent tool for describing the economic process. Accounting is considered as a capital movement identifying and controlling activity itself. In addition, accounting is defined as an economic process mediator. It should be understood that the identification and control functions are included and subject to the function mediation [37]. Therefore, identification and control not promise impartial and correct thinking. Instead of punching, the accounts must be regarded as an operation to establish a subjective picture of the capitalist portion interests. Needless to say, this is counted as one of the economic costs.

Thus, unlike an instrumentalist interpretation, accounting is not separated from the economy and is not just a tool for measuring the economic purpose. Accounting and economics, conversely, are interactive to proliferate, analyze and estimate the movement of capital. It is very interesting that the capital itself can be the subject or object of accounting.

Figure 2 can be transformed to Figure 3 in which accounting is institutionalized by the socio-political superstructure. We can explain the genesis of the accounting institutionalization and its ideological function by using Figures 2 and 3 . Accounting functions as individual capital movement metamorphosis mediator. In addition, mediation does not promise the correct calculation or honest reporting. Among the volumes of capital from individuals working in the economy, at least one party is likely to be driven by arbitrary accounting and the other could be made by illegal operations such as training function. Arbitrary proliferation or unlawful accounting operations constitutes a threat to the socio-economic process integrity. It would be in the interest of social capital movement to require procedures that are governed by an institutional framework to prevent the possible socioeconomic collapse, The future will see a great coming together of understanding of the role of the economic theory of organization together with many problems in agency. Both economic theory and accounting have progressed to the stage where accounting will no longer be the stepchild of economic theory [38].

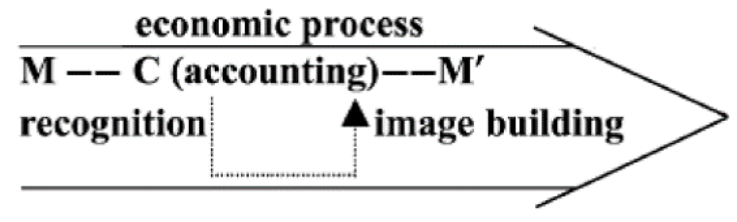

Figure 2: Accounting process in the economy

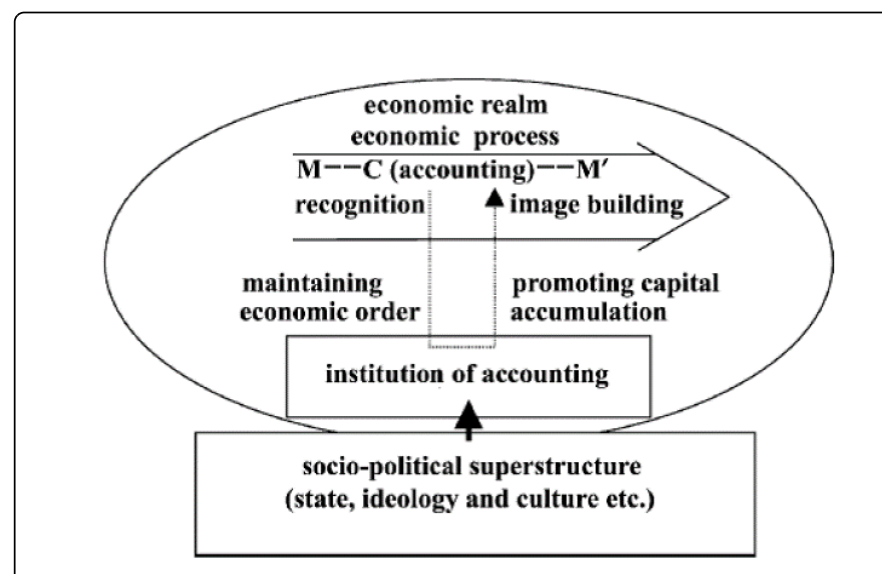

Figure 3: Relationship between accounting and economic institution

Then again, the accounting institution allows some operationscenter to bring benefits to capitalists. Capital accumulation is inevitable for the capitalism development and required by the capitalist economy laws. Within the institutional accounting framework, the operations types that promote the capital accumulation and induce investment are approved and institutionalized. Typical accounting operations are developed institutionalized by laws and rules. This institutionalization is determined and justified by the socio-political superstructure including the state, ideology and culture. The accounting institutionalization, in turn, self-centers operations using the power of the superstructure.

It is important that the institutional framework is produced by the mediation function to increase its role in the social capital movement monarchy. Once institutionalized, each activity is conducted 
according to the accounting framework and the status question. Although the accounting institution began within the economic process, the institution appears to be allowed to drive the resolution of accounting outside the economic process. Since all accounting activities are institutionalized in contemporary accounting changes occur mainly in the field of institutional framework for accounting. Today, the institution accounting plays the mediator role in the social capital movement to maintain the economic order as well as to encourage the capital accumulation.

\section{Theorizing Accounting}

\section{The positive theory}

Watts and Zimmerman in [39] took relief [40-42] which, in turn, brought accounting research to overcome its normative framework for a scientific discipline, referring to the founder Friedman, to develop research in accounting. Both authors have a scientific approach was manifested allowed the accounting studies emerged from a normative investigation to an axis of scientific research called positive theory. Designed as approach pioneers have claimed a perspective that tends to predict and explain the accounting practices demolished earlier theories. The positive theory emerged in the sense of explaining the influence and attitude of political factors, taxes, regulations, compensation costs.... on the management and accounting standards. The politico-contractual approach is based on the policies and contractual costs which are subject institutions. Until the sixties, the accounting information decision-usefulness hypothesis validity put forward the implicit form.

Guesswork in financial accounting have evolved in a normative direction is concerned, in a speculative dimension, selection of the most relevant rules. A decade later, an empirical attempt was made in order to evaluate the normative accounting research. The first experiments have attempted to provide decision-usefulness and a scientific validation hypothesis for accounting information. Highlighting the anticipation of informative volume of accounting data prior to disclosure was the first subject empirical tests. The first empirical studies that have introduced the accounting information to study the market efficiency were emerged by [40-44] frameworks.

Thus, under both an information perspective "and a" contracting perspective, accounting disclosures Have the potential to alter securities prices [45]. These attempts are divided into two columns, those who recognize the accounting relevance using the historical cost figures as an analytical tool [44]. Proponents of this methodology attribute their qualities that justify their rule and longevity in explaining the firm value. Within the firm Suggest that the lack of a market price is replaced by systems for allocating among managers decisions, and measuring, rewarding, and punishing managerial performance. Accounting plays a role in systems and so thesis appears to be share of the firm's efficient contracting technology [21]. In contrast, other analysts give as a conservative design and low volatility on income measures and wealth $[31,32]$, which emphasizes the quasisystematic bias introduced by the accounting use numbers based on historical cost.

This fundamental change in the financial design reporting was accompanied by the legitimacy of the institutional accounting science framework as an information production source. In regulated based on a current explanation of observed practices is intended to predict accounting choices. This program was founded by Watts and
Zimmerman [26,27]. The positive theory has emerged as a cornerstone in the recent process groping in accounting. These schools have a merit in accounting standards emergence and have acquired their scientific aspect and their epistemological status.

Exalted for his controversial, the positive theory has had its share of criticism and even refutation. Beyond its impact, positive approach has emerged to be a combination researcher and the imposition of an empirical meaning of theoretical assumptions. A new horizon dated by a scientific reorientation and a framework for positive analysis of normative prepositions. This excess is due to Milton Friedman and second to JM Keynes. Both authors had published a radical distinction between what-is and what-should be. This scientific orientation gave methodological foundation for the accounting study as a values system, and a redefinition of the researcher-subject relationship. Subject to the rebuttal principle, the constraint of focusing research in accounting practices with regard to the accounting products development that has emerged like an empirical validation process supposed to be presumed realities.

To this end, the majority experiments have evolved a derived from a micro-economic analysis of the financial sphere resting on a methodological study of the theoretical basis events. The pillars of this current analysis were [40-43]. Their objectives were to study the market reaction following the release of new accounting information. Thus, researchers argues the limit informational continuous when the market trend explanation. This convergence has questioned the alleged positive theory of prejudice that the primary role of the disclosure of accounting results of market [46] expectations.

In the same decade [47], based on a similar methodology, have concluded the accounting policies limit to explain market assessment risk. This accounting positive investigation was hired on the financial markets efficiency concept validity. Denying the scientific capacity of traditional research characterized by their normatively, [27] based their theory emphasized the contractual use of accounting information. The positive theory purpose was to establish a set of behavior rules deducting the legitimacy of their empirical validity and which are constrictive a general theory facer financial statements for companies. This modeling of the actor's behavior towards accounting choices has made it possible to establish an assumptions set. Although the factors importance associated with particular methods choice, highlighting the accounting choices motivations made by management, as well as the accounting leadership analogy selection according to the characteristics of their business seems prerogatives.

Ultimately, deploy the developing accounting standards process, exceeding the accounting items study to their explanatory and predictive attitudes, marked the Rochester school genesis. The intention is focused to predict and explain the accounting information producers and users behavior in a neo-classical logical. Nevertheless, economic regulation and agency theories are unanimous. The company is seen as a set of contracts between parties in balance, rational, whose interest is to maximize their utilities [21]. This interest divergence and opportunistic behavior, those are at the origin of some decision-making power delegation in a combination-agent.

Certain limiting or incentive clauses are designed to reduce the interest divergence and affect the opportunistic agents' behavior. These monitoring costs (opportunity) are responsible for the introduction of accounting at the agency heart relationship [21]. And the economic agent rationality is the crux of any accounting problems formulation. 
The financial liberalization increased degree and market integration has enabled the wealth transfer and individual interests' maximization. In this alternative, the politicians have exploited the economic theory of regulation [48] to a transfer of wealth. Taking the political visibility advantages and social weight of major subsidiaries as pressure tools, politicians took advantage from companies accounting results as a technical argument to attract voters. Accounting information is diverted to a political conception. Rochester School made a assumptions number about the firms vulnerability to new regulatory policies and the agency relationship. The "debt" hypothesis is based on the accounting ratios introduction to conclude loan agreements between actuators and creditors by reducing the leaders action when corporate earnings. The interest conflict between managers and actuators is reduced by pressing the accounting indicators profit sharing plan (for managers). These choices can be remedied for political or competitive reasons. The hypothesis that favors size businesses reduces their political visibility. A choice gives the company to destroy the regulatory policies emergence and tax or administrative help fight against the entry of potential competitors on the market.

Accounting practices diversity analysis allowed the context and outcome duplication. To reduce the treatment settings multiplicity, Mouck suggested two axial assumptions. The assumption is derived from the capital advanced school in Chicago based on microeconomic rationality. In this context, the agents have different preferences and knowledge of their situations; seek to maximize their personal interests under contracts whose firm represents the node. In this regard, a type of advanced capitalist order is processed, the market efficiency, rational expectations models, agency theory, regulation, CAPM... are in addition to assumptions and subject to a empirical investigation and sometimes on the tests validity. This allowed the sequential methodology introduction in accounting research. An appropriate instrumentation is advanced for a specific treatment in the accounting practices observation, modeling, formulating testable hypotheses that lead to a reversal or results confirmation.

Positive accounting theory remains very fruitful despite criticism [39]. Some criticize that span the design capital of the accounting process by reducing its social dimension. Decisions tend to meet contractual terms and managing the corporate ratio leverage. Although, opportunistic behaviors that their purpose is to achieve oriented speculative mind with the company pension shareholder ideology rises. Legal or illegal, large companies tend to manipulate their final results or reduce depending on the final assessments, like executive chefs compensation the debt ratio and the company size. The production sector and the market, in addition to other factors, are at the accounting origin choices. The derived information is influenced by the choices and decisions Marxist intensified by a dividend policy characterized by capital concentration and high risks. Conceptually, setting a record that may reflect realistically the company value on the market, is a disproportionate combination.

Rochester School had emerged in a context that seeks to explain and predict the leader's behavior and experts in the accounting policies selection. Positive accounting theory has challenged its epistemological orientations. The North American school has been the some criticism subject, sometimes called the empirical results convergence and sectarianism at research [13-15]. Limited to a specific environment in which the previous transposition research has concerns and precarious consequences model. A theory based on a political vision contractual organizations and having an analytical framework deemed too simplistic [46].

\section{The neo-institutional approach}

The abstract model of the neoclassical synthesis cannot generate instability. When the neoclassical synthesis is constructed, capital assets, financing arrangements that center around banks and money creation, constraints imposed by liabilities, and the problems associated with knowledge about uncertain futures are all assumed away. For economists and policy-makers to do better we have to abandon the neoclassical synthesis [49-52].

Zuker theory had emerged under the pressure of developing a common knowledge (CK). Increasing the society weight and the growing human empowerment being through the collective mediation is splitting with contemporary economic theory. Controversies that develop, externality and the collective welfare supremacy to individual preferences, the office opacity in personal peculiarities respect is to eradicate. The collective reasoning appearances emergence, the ignorance obstacles and the divergence points erected, are the collective act is rectified in the mutual agreement development. The fictional Walrasian auctioneer personification is an adjustment of externality pricing for consistency model. Equal to inaccessible phenomena and suspicion annihilation and mistrust mechanisms are forged to block specular game mutual conflicting identifications "agents are determined relative to a known future they suppose to, while the ones who have determine the Dupuy [53].

The mental act abundance and spread in the other's minds are responsible for the infinite specularity transformation to a common knowledge. However, the transparency and opacity can mitigate the deficit overshoot reflection shape a CK. According to Dupuy a proposition $\mathrm{P}$ is a $\mathrm{CK}$ in a community of subjects familiar to it: real, known to everyone, everyone knows that the others know and everyone knows that everyone knows that the others know, etc., until, to infinity.

Historically the CK concept is anonymous basis. In his treatise "treatise of human kind" Hume argues that all agents must know how to predict the other behavior so that they can engage in activity coordination. The gents adopt cooperative behavior to destroy the opacity and externality, all agent must know what behavior to expect from one Reviews another in order to engage in Coordinated activity. Littelwood proposed one of the famous arguments CK reasoning in mathematical game Martin Gardener. The coordination game notion advanced by Schelling [54], if the gents are more likely to believe that others will also choose the same device, they can be prominent, while such devices become a center focus for their actions are is the basic tool used by Lewis.

Schelling [54] discussed the behavior CK type. Lewis [55] gave the CK formal definition as knowledge niche levels. The author suggested three conditions to complete the CK agreement. First: the balance, the low base. The salient features are more likely to be a CK others. The agreement: three or more agents negotiate an agreement if one party has mishandled the agreement and we do not just judge, a reasonably CK.

Priority (or compliance) seems the second constraint. Even in the agreement or balance absence, the priority is designed a basic complement of CK. If everyone has confirmed a behavior pattern in the past, it is more likely that everyone knows that this is the case, and they are also likely to continue to comply in future (respect for the straight line in the road). These three conditions make possible CK but not fully realized. 
According to Barbier the CK is a Heroic assumption with complete transparency of the group for each individual who composes it always presupposes the maintenance of a pure rationality in a lack of communication between people. All parties are aware of the Convention and its alternatives, or at least anticipate the others reactions, since the decision is a personal individualism optimization. $\mathrm{CK}$ is the gents meeting on "some" knowledge of a given subject. Information is simply a CK between two agents A and B if both (A and $B)$ have the same information and both also known that others know that others have the information... Lewis [55]. The two agents A and B have the first mutual understanding. The spread of information between the various parties is a knowledge transfer from a reduced to a greater degree to its spread in the crowd level. CK is a combination of all knowledge levels dices its beginning to end. CK is entered as a Manichean coordination series, where an infinite secularity is applied by actors with immeasurable capacity calculations, the visualization is easier than its realization, cognitively, it is difficult to think consciously about knowledge orders beyond the first few. Yet, CK is a valuable theoretical benchmark. A great deal of accounting and financial literature Assumes CK [37].

$\mathrm{CK}$ is the language basis, communication, social life [37]. In contrast, considers that the $\mathrm{CK}$ is neutral. The Convention uses as well the wisdom dripping in irony. The irony and the implicit criticism of $\mathrm{CK}$ is largely absent in the accounting context. But compared with other methods of totalitarian ideas-Regulating Dictatorships, doctrine of papal infallibility-CW is remarkably open-minded. American social movements come and shout their ideas Ban child labor! Outlaw abortion! Redistribute Wealth! And CW Responds in its reassuringly predictable pattern. First it dismisses thesis ideas, then it Argues with 'en, and then it reconsiders and absorbs the protest movement's best insights into the mainstream [56] even [37] adds that, CW appears in accounting and control in several forms, though not always explicitly.

Recent research has denounced the absolute reflectivity and the utopianism of total transparency, A weakening of the burden of rationality contained in the notion of $\mathrm{CK}$ (...) to give at least the certainty about the intentions and actions of others. Lewis treats the CK concept like a relative concept and infinite specularity it is correlated. People are satisfied with a finite number of cross expectations as acknowledges. Channeling our attention to the implications of the $\mathrm{CK}$ role in the accounting research and little clarification from the management as accounting rules formation process, accounting phenomena mathematical modeling, changes in stock prices, the financial analysis... although standards can mitigate the transactions costs by playing the contract and the best practices dissemination in the cooperative economy. The accounting policies set the game rules in a cooperative economy. As soon as the pivot rules, legitimacy and effectiveness standards mark. The standards harmonization process is referred to the statement as a CK. Such processes which include a stakeholders variety and supposed to be a challenge when the facer accounting standards as CK. This term has been development potential as a concept in philosophy, economics, and cognitive science.

Although the information is at the research heart in financial accounting and financial markets, these developments impact is still limited. CK thinking may shed significant new light on many of our concerns including financial reporting and analysis, security valuation, managerial control, auditing and information system...but i twill also make important contributions to the fields where this idea originated and developed [37]. However, the CK little push, significantly our understanding of the financial reporting forward for efficient analysis, security assessment, management control, and auditing and information system. Advancement will contribute to a better realization of the business world and accounting information.

In his capital markets description, Keynes JM [57] suggests the professional investors example as participants in a competition in a newspaper to select the six prettiest picture from a hundred faces. The prize is awarded to the competitor whose choice is closest to the competitor's average preferences. Each participant selects, not the faces it finds itself the prettiest, but those which he thinks most likely chosen by the other participants. However, winning is not a resident to choose the photos to the best of his judgment are the best, or even what the average opinion genuinely thinks. Thus, intelligence is devoted to predict what the average opinion expects the average opinion to be and vice versa.

One of the perennial controversies in the accounting history after the Second World War is the use LIFO method. During the postwar period, the tax law in the United States has allowed companies to use the LIFO inventory method for the taxes assessment and the financial statements preparation. Despite the positive significance of the funds with inflation after the war, a large company's number not adopted the LIFO method. By analyzing the adaptation of this method to inventory reasons, financial officers concluded that the LIFO adaptation will increase the cash flow and a decrease in income which can lower stock prices. However, such results are not empirically validated [58].

In these examples, we assume the existence of a similar auctioneer theory like Walrass phenomenon. The others and their beliefs play a crucial role. People disguise their own point of view and do not dare to speak. They keep coming and unite in the same mind state, convinced by a belief that they would require specific information. Without being stupid or incompetent, even as they saw the shade of chooses, they say and do not express what they saw. It is the belief that dominates the visible reality, the influence of the crowd directed collective thought. Indifference to speak symbolizes incompetence, gents keep their own wisdom not to destroy or contradict the collective beliefs. Everyone knows and believes that others know too, but they are silent to maintain the collective knowledge. The silence reinforces the others doubts and the belief in "false assumption" continuously. Individual autonomy is to cloud the collective order. Once a route otherwise breaks the silence so innocent (if child), the running of the event ends and the assumption annihilates. This validity argument is rooted in the Keynes hierarchy rule decision. These rules work and the judgment margin becomes closer to the reality of the market operation. It's like a casino game, the gents involved in games because they saw others who win and they believe it too. In this time of trouble winning spirit dominates the crowd and becomes a common belief, a truth about which way is subject against. How to express the gents and belief in each other's behavior becomes real data.

In business, agency problems are solved by contracts binding resolution compensation manager shareholder value. This value is subject to manipulation by the executive and the carrying value exceeds the market value. The latter adopts accounting increases the current results against lower future earnings in order to increase the share carrying value. Market efficiency is the optimum solution for this agency problem, the information asymmetry between managers and actuators is canceled. The theory is then a CK efficiency to solve the opportunistic behavior. The company, all as each organization is a contractors group whether they are individuals or organizations, mutual, explicit or implicit agreements, whether long term or short 
term. It is an obligation to contribute to the company resources, which, in the court time, every party involved to receive income. The company contract form part of each party and how to align resources are a CK. In this regard, accounting and control is a cornerstone in the operation and continuing contracts. However, the resources contribution, income distribution between contractors, the information dissemination between the parties... are the roles played by accounting and control, in addition to the conflict resolution functions and organization relationships with the business environment. Conflicts that waste resources and hinder the proper functioning of the company affect its image and market value. CK can weaken disagreements and help achieve a healthy socio-economic fabric and a change climate and cooperation whose personal wealth is allocated to human welfare. The practice of carefully collecting and sharing information arises to meet this fundamental demand for a means to preserve our socioeconomic system. Sharing knowledge and expectations is a large part of acculturation and socialization [37]. Sharing information helps resolve family conflicts, work with competitors are settled or avoided.

The social and economic rivalries prevention and resolution are prevented by the information systematic dissemination. Contracts are then execution CK among stakeholders. Controversy and disappointment rise as soon as the visibility of an event is allocated to one party over another. When everyone has an informational advantage, individual opportunism prevails over the collective welfare. The CK introduction is needed to reduce uncertainty and mitigate any individual power to imperfect or asymmetric information. All parties know the rules, the various outcomes probability, but do not know the spot or stops. In a less certain environment is increasingly complex, the accounting entry as an application or a contract in responsibility system [37]. Accounting officers informed not only about the events and other's actions, but also about the game structure and the relative different players positions in the game.

We can think of each organization as a contracts set between participating individuals or groups. The common information provision among contracting parties helps them design and implement these agreements, and help organizations operate [37,58]. Contracts are mutual designs, explicit or implicit, in the short term or long term. Rental space and a lunch date with a friend are contracts. Agents are reasonable in the sense that they do not choose what they do not like. The contracts require each agent to contribute resources in order to receive income. Accounting and control systems perform essential functions in these contracts. They each party contributions measure to resources, income distribution; determine the contract completion degree, and the information dissemination to potential participants in the contract system. Accounting also helps provide CK reduction and conflict resolution. The variables use, which is not in CK contracts, causing the controversy and disappointment.

CK is the observability of an event by all sides. Each party must also realize its observability to another. When some people know about an event, but not the others knowledge when on, they may try to use such information and adopt an opportunistic behavior, creating an avoidable conflict with the CK. Common knowledge can help us to gain insights into many areas of accounting research, standards, treatment information, financial analysis, trading volume, price bubbles, and mathematical modeling of accounting phenomena. Accounting standards serve many functions in society. They help to define contracts class and reduce transaction costs, spread best practices in corporate economy and cushion the financial conglomerates abusive practices.

\section{Conventions' theory}

Dated by its paradoxical form, the term agreement is both very ambiguous and too bright (Gomez). This is an explicit agreement between two or more parties. On the other hand, the convention is a social construction, in implicit and not imposed by nature forms, adaptive rules to reduce conflicts and disorder. In doing so whether implicit or explicit, agreements are a response to chaos. Cement of a community, they can overcome the state of disorganization in giving its members a set of commons Questioning the assumptions of the current contractualist, and given the diversity of social forms that tend to explain the complex structure of human behavior, developed the theory of conventions. Diversification of human behavior, cognitive rationality, uncertainty and sovereign nature of the agents, make organizational forms develop. Coordination and collective responses in the form of agreements are now required to reduce individual opportunism and uncertainty standards and values [59-61].

Corporate governance is erected in a perspective that could explain and develop the organizational actor's action. However, the system representations distribution contributing to unify actions in an axiomatic known to reduce the environment uncertainty, the methodology and the mimetic behaviors and cognitive individualism led to the establishment of the rules common shares: conventions. The agreement is a complications resolution; it is the reaction in a mind common state, governed by common rules, a player facing a circumstance. The agreement is a demonstration of an arbitrary ratio derived to minimize the opacity and the externality of the collective object. According to Lewis [55], it is a coherent body intuition and an implicit agreement regardless of the social contract or explicit evidence, an act of everyday life. The author and his study of language as a "conventional" opposes structuralizes.

Lewis developed the spontaneous coordination game between actors as developed by Schelling [54]. As a symbol of a formal simplicity but is strongly based on cognitive phenomena that gave them a real complexity. Thus predicting the response of an individual does not predicts what the other will do objectively but the way it thinks that, while the first place, that will. Although an infinite specularity is notified, CK harbinger a stabilizing specularity. Each provides its interest in the other interest's unique reports in a disciplinary area, a heterogeneous reflection in the heart of collective welfare. Coordination enhances the cognitive agent's behavior, the concentration instead of individualism. Behavior or collective belief becomes regularity in a population $(\mathrm{P})$. This regularity is estimated to be an agreement if it meets the following conditions:

- Each conforms to R

- Each believes that the others conform to R

- Belief that the others conform to $\mathrm{R}$ gives everyone a good and decisive reason to confirm $\mathrm{R}$

- All prefer a general conformity to $\mathrm{R}$ compliance less than a general $(n-1)$.

- Existence of a regularity $\mathrm{R}^{\prime}$ possible alternative to satisfy the last two conditions

- Statements of facts listed in (1) to (5) are CK 
The condition 6 in Schelling as Lewis, the Convention is to stabilize and remove doubt be publicly acquired its existence conditions and his conviction strengthening.

Several theories include social norms as data set, exogenous rules, even objects in their analysis giving an economic dimension. In contrast, the convention theory opts to make it endogenously those objects of economics [62]. The convention economy figures as a link between microeconomics one hand and sociology on the other, a common standard for setting the economic game rules by conditioning agents to the social contingencies calculation. Given the economic formalism accuracy, the agreements allow the junction of historical and social concerns in the analytical approach such as rules, standards, common knowledge, etc... This gives way to the reintroduction of new data analysis has led to the new opportunities emergence for investigation and empirical modeling. The coordination nature is perceived as real given concrete form to the micro-economic conceptualization of the convention as an individual contract or a market condition [62].

The Convention operates in a social environment or there is uncertainty and rational imitation. It is axiomatic that term stability and conviction are the realization conditions. As the microeconomic analysis unit, the agreement is subject to the constraints and motivations. This is a classical invariant, as the individual, assuming the real analysis enrichment. The term conceptual structure and its existence as an analysis instrument without conflict with the individual autonomy, their admitted to assign an autonomous behavior function, including its usefulness depends on the cancellation of uncertainty subjected to stresses.

The market mechanisms study that are responsible for calling the common rules, have legitimized the concept integration at the economic analysis heart. However, the knowledge relativity that is given to them and passing off as part of its arrangement or a social contract to a systematic procedure for solving economic problems are at the root of the methodological inclusion of the term agreement. The agreement existence that agents imitate in response to an uncertainty situation by adopting a rational behavior, creating a regular form and forward to reduce the undecided ability. The rational imitation generalization, outside the case and the individuals optimizing behavior, allow the channeling of individual reaction. This fact that the expectations will be self-fulfilling and each adopts the behavior of the crowd outside the sovereignty and personal choice independence. The belief degree, in the convention and its attitude to convince, measures the degree of its influence and generalization.

Taking two Keynes citations suggested by Dupuy [53] in practice, we tacitly agreed, as a general rule, to use a method based on a real say a pure convention, this convention is essentially (...) in the assumption that the current state of affairs will continue indefinitely subject we have specific reasons to expect a change [57]. The psychology of a society composed of individuals all trying to copy each other leads that can precisely call a convention judgment [57]. However, Keynes advances metaphorically the notion convention. In logic financial speculation, the author illustrates a general figure of projected activity in the financial markets. On the one hand the specularity logic which agents make choices not expressing their personal preferences, but those with cannon fixed a priori. Henceforth, a specular game consists. Each participant tends not to guess the choices of others, but to anticipate the all competitors' preferences average.
It is remarkable that Keynes and the circular form of the game tends to appear radical ineffability of the assumption of perfect forecast and its subjectivity as evidenced by Dupuy [53], the result is a potentially unlimited specularity which determines nothing, cut because of any objective reference. In contrast to Schelling this type of game is decidable, if not formally at least in practice. However as soon as the agents have a common part of knowledge, then they share a common world: specularity. This knowledge, potentially unlimited, does not lead to anything for Keynes, synonymous with order and stability to Schelling and Lewis.

One form of coordination is made with reference to the salience, originality, uniqueness and finds evidence against the players. When in Orleans, events specularity leads to nothing, but as a bridge crossing between the two rivers, allowing the preferences flow among competitors. This game is finally specular productive and teacher a new agreement, as rational driving based on the imitation faces a radically uncertain environment. Individual choice is characterized by uncertainty and irrationality made of the lack of perfect information and accurate references.

Henceforth agents adopt imitative behavior by referring to the others judgment, we try to fall back on the judgment of the world, which is perhaps better informed [57]. It may be that all agents are united in the same situation, operating in the same reference, but to varying knowledge degrees. Thus appears the difference between the specularity, which all participants have the same knowledge and imitation level that this equality is not the knowledge. Dupuy, when with him, says, in a dialectical sense, the temporal dimension in which it is considered metaphorical mechanism. Whether producer or reducing uncertainty the process takes place in two stages: the first is the specular and speculative game in which everyone watches among other signs of coveted knowledge and that sooner or later by rush everyone in the same direction, and the second is the stabilization of the object that has emerged from oblivion of arbitrary inherent conditions of its genesis. Unanimity who presided at its birth the plans for a while, outside the system of actors who, looking at all in the sense that states cease to cross their eyes and watch another [53].

\section{Accounting Discipline's Emergence}

\section{Social structure of accumulation}

The social structure accumulation theory has occurred late 70 s and early 80s in a collection of articles and books [63]. The basic treaties of this theory are that the alternation between long periods of rapid economic expansion and long periods of stagnation in capitalist history which can be explained by the creation and subsequent a promising institutions growth series collapse. Such a series of institutions referred as a social structure of accumulation.

The first formulation of the accumulation theory, including [63] social structure, adopted the "long waves" concept which refers to regular cycles during fifty years of economic growth associated with the $[64,65]$ advances. This was long waves in economic growth that the new theory has sought to explain.

The regulation theory was introduced in France at the same time that the social structure accumulation theory, developed in the United States. School rules had first appeared with $[28,29]$. The first published work on the school social accumulation structure [63], appeared shortly after the French edition. 
The regulation theory holds that capitalism had experienced a sequence of accumulation plans. Each cycle is associated with a particular regulation mode that governs the accumulation process. School rules may be better designed for the "Fordism" concept. The name is given to the post World War II accumulation's system. Fordist accumulation regime is based on assembly line production methods and working class mass consumption.

The regulation theory and the accumulation social structure offer new theoretical frameworks to analyze the current and long-term capital accumulation. Both approaches use Marxian categories and concepts for this purpose. Yet both approaches abandon the Marx traditional formulations on this subject. These two theories have differences as well as similarities. A similarities and differences consideration may help in better understanding the two theories.

The accumulation social structure (SSA) provides a theoretical and historical account of the long-term dynamics and the economic institutional capitalism growth in the United States. As formulated in the beginning, the SSA covers economic, social and political institutions that constitute the environment within which the capital accumulation work [63]. Institutions that form SSA experience a life cycle reported with long swings in economic activity. As old theory, relatively rigid, SSA follows a long period of stagnation. As a new potential evolution theory, the SSA promises a long period of recession.

The SSA approach provides that new institutions theory must be in place before the next prolonged recession period begins. In SSA down, although the stagnation mine a resource base for the institution, it is not easily reformed, due to conflicting interests, the old political coalitions, fixed barriers, expectations and ideology. The historical account [63] illustrates SSA process in the United States history. Highlighting the barriers that constrain institutional adjustment to changing conditions, the SSA approach suggests that institutional rigidities can lead to a long recession cycle, a goal that can perpetuate stagnation over a long period. On the other hand, a new SSA construction should begin before the next recession long period can take place.

The current crisis has revived the interest in Marxist crisis theory. The accumulation social structure theory represses crisis by analyzing relatively long accumulation periods separated by intense crisis periods. These periods, more stable, is a capitalism stages succession. Crisis times, as they hold the possibility of developing a widespread crisis in the capitalist production mode are particularly foregoing periods of capitalist development crises [66].

The current economic and social crisis has led Marx's theories at the debate forefront. Traditionally, Marxist theory has sought the origin of capitalist crises in abstract economic laws and changes in capitalism. These theories have been developed and refined in the capitalist's context at the end of the nineteenth century crises and 30s. This appeared to presage the end of capitalism and demanded the transition to socialism as the only solution. Subsequent recoveries of capitalism at the beginning of the century and after World War II led to the current Marxian theory survival. Today, it is widely recognized that the capitalist development theories must represent progressive, recurrent periods of growth as well as the relatively healthy periods of chronic stagnation. This realization has revived interest in the Marxist tradition in the long Kondratieff cycle.

This crisis theory, do not neglect the general trends and form of crisis identified in the Marx theoretical tradition. A theory rooted in the capitalism basic structures. Nevertheless, it is concretely manifested in the historically capitalism contingent failure stage which was formed by an institutions complex set that served to stabilize directly the capitalism inherent shortcomings as a production and social organization mode. In addition, the factors most historically located may be required by this perspective in the analysis.

Global neoliberalism was a further break with SSA precursor. While global neoliberalism has been relocated to broadly reflect the relationship between global and national aspects was therefore different in contemporary SSA compared to the previous era. The SSA regulated state after war can be thought as a national regulated SSA collection that was internationally connected by appropriate international institutions. By contrast [67-70], the global neoliberal SSA exists in its most pure form and at transnational level, where neoliberal principles have become completely dominant as practiced in institutions such as the WTO, IMF and the World Bank. Global neoliberalism is a transnational structure with local structures nested inside it, with the variation in the extent to which these local structures reflect the neoliberal model.

\section{Accounting and neoliberalism}

Each SSA has a wide variety of institutional components, leading a large part of the economy, politics and the company culture (ideological level). Each institution's taxonomy needs to be somewhat arbitrary. In the following, the institutional changes that have made the transition to global neoliberalism are grouped under four headings to facilitate the comparison of local economy structures. These headers are globalization, neoliberalism, weakened labor, and financialization.

Globalization is localized in several developments. Firstly, it means a significant increase in the international capital movement, goods and services. Barriers to the goods free movement, capital and services have been greatly reduced. Capital movements deregulation was an important development in spite of the growing hospitality state for foreign direct investment. A technological development in the information and communication sector was important. This increase in mobility at the physical productive capital and financial capital intensification of international financial activity was very remarkable and significant.

The East European regimes collapse, has allowed a rapid transition to capitalism in the Soviet former. Process slower and more measured transition was initiated in China with the post-Mao: the economic reform process. These transitions were originally high inventories of raw materials, major investment opportunities, and massive reserves of the labor market. This provided new markets for global capitalism. These developments also mark the end of support and alternative sources of aid, economic and military, to the less developed countries.

The most consistent result of this new mobility is the production fragmentation in often distant across borders components. These components reintegration in overall production chains both trade and internal logistics operations between transnational corporations. Every part of the production process can be located in a particular place can run this process in the most profitable way.

In a Marxian perspective, consecutive class relations transnationalisation is central. The financial system globalization with the capital controls elimination and electronic reliefs include, transnational, those legitimacy to a portion of the surplus product under capitalist production relations. This is accompanied by full consolidation in the production act in developed and less developed 
countries. Thus an operations transnationalisation by the capitalist class is brought into relation with a transnational working class. The neo-Gramscian school in international political economy [71], the Amsterdam School, and political sociologist William Robinson studied the formation of the transnational capitalist class.

Capitalist production globalization and class relations arise, inevitably, the question for the creation of transnational institutions to govern the economic relations. Robinson theorized the emergence of a transnational state unlike traditional members of the United Nation system. The new transnational governance institutions do not focus sovereignty over a particular territory. The massive trade liberalization had conflicting results, leading to increased competition on the production market and increased by the mutual cooperation hand possession, joint ventures, sub-treatment concerns tense [72]. A wave merger had consolidated capital across borders, leading to the larger number firm's creation.

Neoliberalism is a coherent entity that includes multi-level economic policy institutions, theories and ideology. Neoliberal institutions include those busiest shown to promote the growing franchise the world economy as the World Trade Organization [73] (WTO) and the International Monetary Fund (IMF). The "hollowed out" of domestic state could be included here as many thought tanks and private political organizations.

At the neoliberal policy, liberalization, privatization, and stabilization of economies are major priorities. First, liberalization refers to free markets and companies' state rules, most especially is the barriers removal to cross-border goods and capital movement. We are seeing declines a public enterprises privatization to private owners also contracts the services of private companies that have been traditionally provided by the state. Therefore, stabilization refers to a change in monetary policy to prevent inflation instead of encouraging the reduction of unemployment low. Fiscal policies of the state are directed to reduce taxes on capital by reducing or eliminating social programs. The prevailing theory is a version of the free market as the neoclassical economic theory, associated with names like Milton Friedman. Neoliberal ideology is marked by the glorification of individual choice, and the market. The state is seen as an enemy against individual freedom and economic efficiency.

As is evident, neo-liberalism is strongly related to the globalization onset. The neoliberal free trade policies and the control cancellation over capital movement, as well as the general "hollowing out" of the state, encourages globalization of production, trade and class relations. Neoliberal policies have promoted the elimination of capital controls. The resulting capital movement freedom has changed the decisive class balance of power in the capital service.

There is another aspect when the relationship between globalization and neoliberalism. Protected in the developed capitalist countries domestic markets have been invaded by the increasing import competition. As a consequence, the support of capital assets by the regulations of the state began to decline. Thus, large corporations have found the competition as a threat to their survival. They turned against the regulations of the State and expensive social programs [74]. Thus, globalization has promoted neoliberalism as neoliberalism has promoted globalization.

\section{Financialisation multidimensional}

Financialization, its basic meaning, a Marxist perspective, is the path of a growing percentage of the surplus product in the capitalist economy by financial institutions. This has dramatically increased the financial capital role as a tool for growth. We are witnessing a strengthening trend of diversion to investment in the productive sector of the economy to the financial one. The manufacturing industry has become increasingly dependent on loans for investment and consequently the health of the bond markets. The short-term returns and quarterly returns has become the success measure, while executives move from one company to another, losing any anchor even industry in the company's fundamental health [75]. This was facilitated by the neoliberal push for deregulation. The following diagram clarifies the accumulation path leads through the process of financialization.

Following the financial collapse at the beginning of the Great Depression, banks and other financial institutions are highly regulated and have played a secondary role in the economy. These limits were phased out in the global neoliberal era. This allowed banks to expand into new areas of financial activity and began, increasingly, to act on their own accounts. Financial innovation has brought new and exotic instruments to market. Increasingly, government agencies have lost the ability as well as the will to regulate its activities [76].

The control's abolition, allowed the capital's movement and the financial activity's internalization, in general, across borders. International trade has grown in volume and speed. Many European countries have merged their currencies in the euro area. The mobility of entire countries, submitted transnational financial capital control policy of international financial markets. Financial crises have become more frequent and contagious, but until last major financial accident, were confined to those who deserve judged lack of discipline.

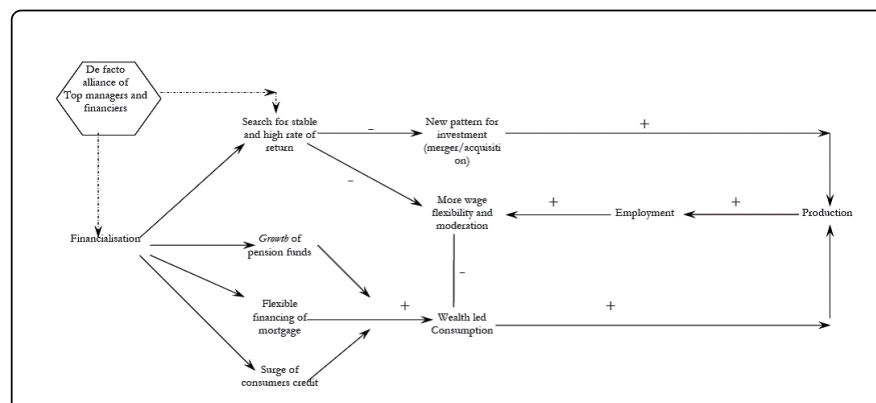

Figure 4: Finance and accumulation system

The conflict between capital and labor is usually at the heart of any Marxist analysis, and global neoliberalism is no exception. Neoliberalism is based in part on a drastic change in the balance of power between capital and labor. In global neoliberal regime, a change in models and production locations, the possible development of a new work organization strategy of "specialization" taking advantage forms improved communications technologies and new changes in transportation, capital entered into force to use the threat of moving production (platform), or the actual relocation of production from one place to another as a means to more effectively work organization (offshore). These terms have become important means for establishing the power of capital and control wages and working conditions of the working class [70].

A prominent feature of global neoliberalism is the weakening of the movement, very apparent, unionism in most countries. In industrial relations, the power has shifted significantly to the employer. In the neoliberal era, many unionized workers in the primary sector were 
treated as workers in the secondary sector in the previous SSA form. Wages declined, benefits disappear, and job security has been abandoned. The flexibility of the labor market has become a nearly universal formula and strategy. New production systems were abandoned in the neoliberal era. Instead of technology for mass production of the previous SSA, many industries have shifted to new systems such as flexible specialization and classroom management worldwide. The neoliberal era is now over a quarter of a cycle, dating from around 1980, focuses on various issues including their neoliberalism and progressive weight "finance" in the economy that is accompanied by various economic, social changes, legal.... A common view is that the rise of neoliberalism is explained by the role and the growing power of finance in the political economy of capital. According to Dumenil and Levy [77], neoliberalism is the phrase of the desire of a class of capitalist owners and the institutions in All which their power is Concentrated, All which collectively we call 'finance' to restore... the class's revenues and power... Some analysts look at the rise of what might be called "financial dominance" as a fundamental development that not only explains the emergence of the neoliberal order, but also the shape associated with globalization in this era [77].

The growing role of finance in the economy in recent decades can be best captured not by the idea of dominance of the financial sector, but the concept of "financialization". This suggests a progressive role of finance in economic activity. It will be played here that the immediate cause of financialisation recent decades, is found in the radical neoliberal restructuring changes. However, financialisation also has deeper roots that are unrelated to neoliberalism. This interpretation of the relationship between neoliberalism and financialisation clarifies the differences between the form of financial predominance, which is presented at the end of the nineteenth century, and the twentieth century's, and the current neoliberal period.

\section{Neoliberalism and the accumulation social structure}

The particular institutional form of capitalism has regularly changed made mutual changes that incurred neoliberalism centuries ago. Neoliberalism can be considered as the final institutional form of capitalism. The SSA theory provides an analysis of periodic changes in the capitalist institutional structure [67-70]. The SSA is here interpreted as a coherent capitalist institutional structure that promises profitability, thereby forming a framework for capital accumulation.

According to the SSA theory, each structure works effectively to promote profitability for several decades. But sometimes it ceases to do so; this leads to a period of crisis, which eventually leads to new dependent SSA potential institutional changes through each country.

The construction of the SSA post World War II was completed during the last forty years and has worked effectively around the seventies. The SSA has been characterized by an active regulation of economic activity in the states and in the global protection system is well developed. Cooperation between capital and labor has become significant and a form of co-respective and competition between large corporations. SSA post-war was a significant departure from the past, when the state had played a more limited role in the economy. Individuals mainly defended this policy let pass. The post-war system is often perceived as a result of the historical break signified by the great expansion in the state role in "regulated capitalism" period.
During the seventies, the SSA after the war has entered a crisis period. End of the seventies, a new SSA began to take shape early in the USA and the United States, called "neoliberalism." Its main features are similar to the capitalist market version pre-Great Depression. In the most world countries, although in the USA, the term "liberal" refers to what the state should stay out of the economy control.

Its main features include the barriers removal to goods free movement, services, and especially capital, through the global economy. A narrowing of the state role in the economy management and regulation, public enterprises and services privatization, state's social programs reduction, change regressive taxation forms, and replacement co-respective behavior by large corporations with unbridled competition. Neoliberalism has an ideology associated with the "free market" with an annihilation of the state positive role outside its corrective functions.

The neoliberal SSA has meant a major restructuring of the global capitalist system as well as privatization of public institutions in the U.S., the UK and many other countries. However, some countries have adopted the capitalist neoliberal model, such as the Scandinavian countries and Japan. The neoliberal institutional structure qualifies as a coherent SSA has a sustainable capitalist institutional structure that has led to a growing rate of profit in the major capitalist countries and formed a solid framework for capital accumulation.

\section{Renewed Financialisation at the Expense of Financial Stability}

The community takes control of innovation and establishes rules so that they attribute to the efficient allocation of capital, credit and risk... without compromising the public good dealer that is crucial to financial stability [75].

Financialization, which provides the path of a growing percentage of the excess product in the capitalist economy by financial institutions, has its origins in a Marxian perspective. The recent growth pattern in OECD countries is strongly based on the financialization process. Such a system is far from the institutional logic based on wages reports, production and mass consumption known as logic "Fordism". The pyramid hierarchy is reversed when the financial economy. Now, the monetary and financial flows are at the top. This has dramatically increased the financial capital role as an economic growth instrument (USA, UK). There has been a strengthening of a trend sector investment in productive economy to the financial sector diversion. The manufacturing industry has become increasingly dependent on loans for investment and consequently the bond markets health. Running short-term and quarterly companies results have become the success measure, while executives move from one company to another, even from one industry to another depending on the profit rate, which affected the company's fundamental health and its stability [75]. This was facilitated by the neoliberal push for deregulation. Following the financial collapse at the beginning of the Great Depression, banks and other financial institutions were highly regulated and have played a secondary role in the economy. These limits were phased out in the global neoliberal era. This has allowed banks to step up and invest in new areas of financial activity and, increasingly, to act on their own accounts. Financial innovation has brought instruments, both new and exotic market. Gradually, government agencies have lost the ability as well as the will 
to regulate and supervise the market volatility activities within reasonable intervals.

The control abolition allowed the capital movement, sometimes not divine and financial activity internalization (usually across national borders). International trade has developed in transaction volume and velocity. Many European countries have merged their currencies in the euro area. The change in economic policies in most countries submitted transnational financial capital to control players in international financial markets. Financial crises have become more frequent and contagious. Until the last major financial accident, these accidents were confined to those who deserve to be judged by the lack of discipline. The conflict between capital and labor is usually the heart of Marxian analysis. Global neoliberalism based in part on a drastic change in the power balance between capitals and labors not an exception. Currently there is a change in the production patterns and places and a development of a new strategy for the organization of work by "specialization" that took advantage from communication technologies. Mobile production (platforms), or the actual production movement, from one place to another as a labor means (offshore), led to a threat of constraints. These terms have become important means for establishing the capital and power controlling the wages and working conditions [70].

The current neoliberal sought to put a device weakening very apparent movement unionism in most countries. In industrial relations, the power has shifted significantly in spite of the employer. In the neoliberal era, many unionized primary (under the old form social structure of accumulation (SSA)) were transformed into secondary sectors. Wages fell, missing benefits, and job security has been abandoned. The labor market flexibility has become a nearly universal formula and strategy. New production systems have been presented in the neoliberal era. Instead of technology for mass production of the previous SSA, many industries required new systems such as flexible specialization and class management worldwide.

In recent decades, the finance role in the economy comes from the financial sector dominance and the "financialization" concept which suggests a finance progressive role in economic activity. It is here argued that the immediate cause to financial aspect rising is found in the neoliberal restructuring, rather financialisation which explains the neoliberalism rising. However, the term also has deeper roots that are unrelated to neoliberalism. This interpretation of the relationship between neoliberalism and financialisation clarifies the confusion between the form of financial dominance (which is presented in the late nineteenth century and twentieth century's) and the current neoliberal period.

A recent literature about phenomenon is presented. The "left" term definitions vary according to the authors. Epstein [78,79] defines the financialisation process as Financialisation means clustering increasing the role of financial motives, financial markets, financial actors and financial institutions in the operation of domestic and international economies. This definition suggests a quantitative expansion of the finance role in the economy. Possible changes include the fact that finance has become more powerful compared to the nonmonetary sector and the link between finance and the latter, becomes tighter or looser fit.

To address this test, we examine the historical background of the theme "financialization" in the neoliberal era, we mainly basing on American cases. During the twenty years of the twentieth century, the financial sector in the United States was largely unregulated. This period is granted with the widespread and excessive speculative financial fraud. At the twenties end, the stock market crashed followed a few years later by the great movement of bankruptcy. This wave is the predominance of unregulated funds result which had been a major factor in the depression severity.

Arrighi and Arnold $[80,81]$ defines financialisation as the ability of financial capital to take over and dominate a little less, all activities of the business world identifies the financialisation process in the seventies as a change in the macroeconomic policies and raises several issues in accounting research [1]. This "financialization" scenario is that analysts post-Keynesians have reviewed how basic and unsustainable trend had eventually lead to crisis. This is the creating additional credit and debt process, along the following lines, which were the crisis cause.

This has influenced strongly the finance new regulation and subsequently formed the postwar SSA basis. Financial institutions in the developed capitalist countries were typically owned by the state or regulated. In the United States there were controls on interest rates made by public authorities. Financial institutions have been segmented by the type of business permitted. The entry in the financial markets has been tested internally, and banks were protected against bankruptcy. Tight regulations have forced the financial sector to promote capital accumulation in the non-financial sector [82].

The change in the financial sector role in the neoliberal era did not involve just a quantitative expansion of its activities and profits. These financial institutions, including the giants among them, have exploited their role as "servant" and accumulating non-monetary capital to continue harvesting their own profits by financial activity. The new financial instruments creation and sale (financial derivatives), have replaced the long-term borrowing relationship with the non-monetary sector that had prevailed in the regulated capitalist SSA. However, financialisation has not involved a new dominance of the financial sector, but rather a growing independence between financial and nonfinancial activity.

\section{Accountable institutions and regulation}

The accounting institution significance extends an abstract concept to a real settlement. First, the financial institution is considered as a theoretical concept to analyze activities and economy real systems. Figure 4 shows the accounting as a theoretical tool that connects to the economic process and the socio-political superstructure. Second, in terms of form, accounting is considered legal framework includes laws, regulations and standards. In the opinion of the traditional accounting schools, accounting institution was seen as a framework to duel body values and exchange laws.

Third, the financial institution is considered as dynamic system and setting each accounting activity. When analyzing dynamic real phenomena of accounting, we use the accounting rules concept. Whereas the legal framework expresses an accounting static dimension, the accounting regulation concept expresses a dynamic dimension. Thus, referring to the limit "institution accounting" we should distinguish between three meanings explained above.

In this sense, a number of authors chose to focus on the settlement of accounts in order to develop an international comparative study. Accounting as regulation seems better suited to the comparative analysis of international accounting institutions to the concept legal framework. 
In this theoretical context, we present a summary of regulatory accounting relationship of the economic process as stock-flow analysis function. The mediating role is to negotiate the economic process and develop both real economic distribution functions by integrating them into the contemporary dimension of capitalism. First, is the benefits distribution function among stakeholders? Second, is the economic resources allocation based on the financial market?

In addition the accounting real functions may be divided into two types, namely, micro compatible regulation and macro-accounting rules. The accounting rules relates to the negotiating function of the economic process. The micro computable regulation is concerned with the benefits distribution function among interest groups such as shareholders, creditors and directors. The macro-accounting rules relates to the economic resources allocation function (money) on the capital market.

This accounting dual role is significant considering how accounting regulations negotiating the economic process and examines how this is allowed settlement-center accounting activities. The micro computable regulation governs profits division or parties interested income in the calculation methods. The term "micro" means the different economic actors interest coordination. In general, the micro computable regulation is driven by the legal framework, such as acts of commercial codes or society. The micro computable regulation governs the division of profits or income from the parties concerned, with a right to corporation's calculation methods or distribution.

In general, the micro computable regulation is driven by the legal framework, such as acts of commercial codes or company. The failure in the income distribution for the actuators could result in conflicts among interest groups, which leads to a call to a micro computable settlement for legal prescription. However, this does not promise a correct or impartial distribution. The income distribution method is distorted and biased to favor the capital accumulation. Sometimes the allowance or depreciation expenses are deducted from income as a cost or expense. But special allowances like to improvise against poor anticipation of risk is essentially no cost or expense but rather an appropriation of profit.

The macro-accounting rules, on the other hand, are involved in the economic resources allocation and the financial market to provide accounting information. The term "macro" connects to the monarchy of the macro-economy in which social allocation of economic resources is assumed to be controlled by the market and the state Historically, the macro-accounting rules originated the U.S. securities legislation in the thirties. The main instrument of macro-accounting rules, therefore, is the stock market. The macro-accounting regulation is primarily concerned with information accounting regulation.

On the stock market, accounting or disclosure information have to be more specific, a very important role when the economic resources allocation and influencing investor's decision making. Therefore, investors need appropriate accounting information that is relevant to their decision making. However, it is unclear that the accounting information is really useful. While the need for disclosure of accounting regulation has been the subject of intensifying discussions, the current policy has swung between the regulation and deregulation, while it is often said that markets require fair and impartial transactions, it is more of a myth than reality.

The macro-accounting rules sometimes allow the biased reporting of information and encourage investors to behave in a certain way [36]. The macro-accounting regulation is subject to national economic policy under power of the capitalist state. Macro-economic regulation and accounting policy are influenced by complex relationships between the common social interests and class interests. Therefore, the macro-accounting rules leans much politicization of economic policy. In the macro-accounting rules, there many issues including intrinsically body and the referral process which accounting standards are purified.

The macro-accounting regulation is strongly influenced by economics and contemporary theories of international finance. In this issue, accounting undergoes a transformation from traditional operations based on econometric operations based on economic theory. Therefore, the macro-accounting regulations tend to lead to certain types of policy and ideology. Contemporary economics could not be considered to achieve balance in the Pareto model but as the study resulting imbalances. The state active role interposition plays a significant role in the economy management. The state has been so involved the accounting practice development and in determining the reporting and accounting policies [83].

The accounting information has an ideological function because they are used to legitimize specific activities or rationalize behavior and accounting reporting as a tool ideological hidden through the income distribution and wealth in the economy. Accounting is also regarded as a speech with a particular rationality mode calculated to be up and be a conflict between different social classes. At the microorganization, the accounting calculation is like a "cake" available for distribution. At the macro level, these numbers influence tax policymakers, salary negotiation, and economic restructuring.

\section{Relationship between neo-liberalism regulator and financialization}

It is widely recognized that a radical change in the neoliberal capitalism regulator's state role occurred around the eighties. It is also known, at least by specialists during the neoliberal era, a financialisation process has intervened in capitalism. However, the relationship between these two developments is not without adverse effects. A view is the idea that the power financial capital growing, coupled with financialisation leads to the current neoliberal restructuring. However, this view has given serious problems.

Given that neoliberalism represents the financial capital victory or some broader finance categories, then two questions arise: if this victory was it signed? And how the finance was able to achieve such dominance? We allow, first, to consider the first question. If a capitalist interest (financial and identifiable) could cause the neoliberal transformation beating a capitalist interest (pecuniary and nonidentifiable), there should be a conflict proof. The non-monetary capital, presumably embodied in the non-monetary gigantic corporations, now shaking the world, brought in such conflict evidence.

Neoliberalism took root first in the U.S. and the UK at the seventies end. In the USA the transition to neoliberalism appeared to have unified the capitalist class support, apart from a few non-conformists. A capital major part had earlier supported the regulated capitalist SSA, in collaboration with organized labor [74]. It was the desertion of this covenant by the massive capital allocation in the seventies they did allow the restructuring to precede so quickly, changing the current neoliberal. In the UK, when the Minister "Thatcher" began the neoliberal restructuring in 1979 [84], there was some opposition to the capitalist class, but he did not score a financial conflict against non- 
monetary capital. The initial opposition was due to the ultratraditionalist, financial aristocratic classes and industry who reacted to the Thatcher choice on the upward capital mobility $[85,86]$.

Some policy's supporters saw the financial predominance explains neoliberal transformation generally defined by the "finance" and that challenge becomes consistent with the arbitrage absence between financial and non-monetary capital segments. Dumenil and Levy [77] define finance as: Both institutions (the financial system: Commercial and investment banks, pension funds, insurance...) and Individuals, [That is,] capitalists - gold fraction of capitalists since some capitalists are more 'financial' than others. The capitalists specified to be excluded from "finance" include the "small shareholder or the small firm owner who "does not belong to actually finance" and corporate managers.

Thus, it appears that the finance includes not only financial institutions but also all large-scale capital owners, excluding only small business, small shareholders and directors. That is to say, turning finance more or less coincide with the capital large influx, or perhaps with mutations at smaller financial institutions. If the capital large influx, together, supported neoliberalism, then it is not surprising that there was no apparent conflict in the capitalist class on the flight. Small business, still predominantly have supported a liberal regime. In the U.S., this was the main opposition to the new finance and capitalism regulated institutions after the war. In addition, the huge company's directors have "harvested" fabulous wealth in the neoliberal era in the form of wages and subsidies have soared in countries that have undergone a neoliberal restructuring.

However, if finance is defined broadly, to include any capital flows, thought that neoliberalism represents the victory and the finance interests have no explanatory value. The capital flow is part of every coalition and judgment because capitalism has reached the monopoly power stage. Most of capital flows was supported, although with regret (interventionist) by the welfare state.... This was attributed to finance its weight on the global scale. The conflict absence in the capitalist class is understandable. The question is whether the capital flow has abandoned regulated capitalism in neoliberal restructuring favor in the last seventy years?

If finance is defined to refer to an identifiable capitalist financial segment, then the second question: how did the financial capital reached a dominant position? According to this view, the nonmonetary capital was dominant in the postwar SSA. In the USA, banks and other financial institutions have planted this restriction period through. Neoliberal ideas became dominant in the early twenty-four years; including the new belief that the settlement was "harmful free market" it was always better.

The financial sector was liberalized by the United States with the new laws legislation in 1980 and 1982 (financial deregulation) that has allowed the financialisation process to develop. It seems that the neoliberalism beginning restructuring, has paved the way for financialization.

The trading companies financial benefits in the United States as a share's total corporate profits before tax, up to 1989 (nearly seven years after the financial deregulation), began to rise close to twenty percent of total profits. After (1989), financial profits as a share's total profits, showed a strong upward trend, although with large fluctuations around this trend. Thus, in the United States, the rapid growth period in financial profits, relative to total profits, has become very significant after neoliberal financial sector restructuring. This is consistent with the view that states that the neoliberal structure led to the financialisation rather than the alternative view that the amplifier provides power only due to financial sector led to the neoliberal restructuring [87].

However, every bank considering some risks, especially if the banking, the various productive enterprises involve borrowing medium term. The marketable securities issuance choice always promises more security. The idea is to keep the wealth forms to have the ability to manage, instantly changes and make threat against "accidents" that may occur. In this way, the capital sum assured, even with the new products risks and new processes that are new threats. This explains the existence of an underlying trend towards increasing the financial motives role, financial markets, financial actors and institutions in the domestic and international economy operations.

The trend towards financialisation can be held in check by institutional agreements, which ultimately reflect the various classes and groups relative power. Financialisation was mainly kept in check by capitalist SSA regulated institutions after the war. However, the financialisation trend has exerted pressure against the various regulations that were constrained during the postwar SSA. Towards the end of this period, the financial institutions have found various ways to partially avoid the regulations. The neo-liberal ideas rise in the $70 \mathrm{~s}$, the pressure they built quickly demolished the financial sector regulation, in particular, joint with neoliberal arguments against regulation in general to provide bankers more freedom.

The finance predominance does not explain the neoliberalism rise in the 70s. The neoliberal SSA rise was due to the crisis of the post-war structure. The SSA was no longer operating effectively to promote profitability. The global economy has become very chaotic in this decade, with large fluctuations in the essential commodities prices, inflation, and currencies overvalued exchange rates. The profit rate has collapsed in the major capitalist countries during this decade. A Keynesian technique for economic governance, which was effective, was in the 60 s, did not appear effective for treating a combination of high unemployment, high inflation, and chaos in international financial markets. In this context, a search for a new institutional structure for capitalism took path.

Harvey $[85,86]$ discusses if neoliberalism was a threat to the elite classes and against the chaos they saw in the 70s. He argues that neoliberalism was a project to restore the conditions for capital accumulation and to restore the economic power elite. While neoliberalism was not effective in restoring and rapid accumulation of regulated capitalist era, Harvey noted that restored the power and the elite wealth, noting that the biggest beneficiaries in United States were financial, CEOs of large corporations, and owners of some new areas such as computers, the Internet and media.

This analysis identifies the capitalist class as a whole investigators neoliberalism. However, observing that neoliberalism took most of the capital does not provide a full explanation for his appearance. There were good reasons why the liberal institutional structure was abandoned after World War II in a regulated capitalist SSA favor. The latter produced a more rapid economic growth in capitalist history. It is not clear that in the neoliberal era of the 70 s, the structure was the only way or the best way to restore the capitalist power. Some unethical capitalists in the United States, such as investment banks, during the $70 \mathrm{~s}$, urged a new institutional structure and regulated capitalist who overcame the previous structure shortcomings.

One factor that led to a new liberal SSA was, undoubtedly, a trend against the imaginary perfect past. Once the free markets time (free 
government regulation and the need to negotiate with the unions) were to limit the control exercised against the capital influx. Strong unions seeking to increase wages exert some control over working conditions, regulatory state businesses taxes and limit their action freedom on the market. With profits down, the desire to wages rigidity, limited control over working conditions, impose taxes on capital, and obtain sub-rules out government intervention has made the old liberal ideology as attractive to capital.

\section{Conclusion}

However, the call for an idealized past is not the only factor that constituted support for neoliberalism. There were several factors in the specific historical conditions of the $70 \mathrm{~s}$ that help represent the neoliberal SSA rise at the end of 1970.

First, (during 1948-1973), capitalism began to be increasingly globally integrated economies. What promised to national markets, relatively isolated in the major capitalist countries to be more competitive, as companies in the United States, Europe, and Japan invaded the markets. Therefore, the early 70 s was to establish corespective competition relations in the long term, such as autos, steel, and electrical machinery. It was dominated by a few giant corporations in each country. As the power monopoly was eroded, the abundant capital flow allows us to consider the long-term regulations benefits against state regulations that had stabilized the key relationships in the system. Rather, fear for their survival in the short term in the new competitive environment, large companies have turned their attentions to reduce costs and increase controls. This provided a reason for large companies to desert their coalitions (which were created and which had maintained the postwar SSA) with previous labor force. Increasing global economic integration, had embezzled large to small business, which encourage large companies to adopt the long investment policy perspective.

Second, the Great Depression was a major factor in convincing dominance supported by a regulated capitalist SSA capital. Its severity has threatened the capitalism survival itself. Fear a depression return after World War II, it seemed that the government, with concessions to the working class, the only guarantee for the survival of the capitalist system. After 70 years as the Great Depression, is seen as a particular historical accident, which probably cannot be repeated. A major reason for large companies to support the settlement of the state is revealed by the duality compromise between capital and labor that was more abundant.

Third, the threat posed by the socialist state system was an alternative in the 40s. The late '40s, the socialist bloc, seemed very strong in Europe and China. Communist and socialist parties had emerged with great people at the capitalist countries expense. These great successes had created a compromise with the work in this period, to avert the revolution threat. In the last 70 years, the threat against the socialist revolution had become a priority for the West, as governed communism seemed to stagnate and lose its previous revolutionary fervor, while supporters of the left in the capitalist countries had accepted a reformist role. In this period, the collective institutions well-being and strong unions seemed unnecessary as new SSA components.

The factors mentioned above can explain the neoliberal SSA emergence in the late 70s, in the previous crisis context. Neoliberal SSA was reinforced in the late $80 \mathrm{~s}$, when the Socialists and alternative systems of the state have disappeared in Europe. China has become increasingly integrated with global capitalism. In the 90s the neoliberal SSA stability stays to defend the Labor Party power in the United Kingdom and the Democratic Party in the United States, the neoliberalism twins' birthplace. This led to further the neoliberal SSA strengthening in these countries, instead of the far corner which had been suggested during the election campaigns.

Thus, neoliberalism is not the only finance's capital interest; it represented a capitalist's class interests that changed, relatively, unified under specific historical conditions. Financialization, as long-term capitalism trend, has been held in check by the SSA after the war, and was released only after the neoliberal restructuring has climbed in the last 70 years. Once confirmed, the neoliberal SSA provided a favorable environment for the financialization.

Recently, financialisation is not treated like a simply neoliberalism consequence. We can identify a strong trend towards financialisation in the capitalism basic processes, once it reaches the corporate capitalism stage. The increase in the organization form in the nineteenth century turned capitalist ownership movable property to business property. Capital possession was transformed from direct company's ownership in owning securities. This represents the company's indirect ownership.

This provided an opportunity for capitalists to escape the main problem they still face as individuals: the tremendous risks are integrated into capitalism by new technologies and new financial products. Every industry is down as a real productive business is always in danger of erosion due to competition from new products and new processes. So, capital is always looking for ways to minimize or destroy such risks. There are various ways to gain some protection against such threats, including the monopoly power pursuit or protection by the state. However, changing the real capital ownership to financial capital is the best way to isolate the risks inherent in the capitalist market. This is probably the reason for the huge industry Rockefeller, born in the oil industry, was soon diverted to finance real estate.

\section{References}

1. Bezemer DJ (2010) Understanding Financial Crisis through Accounting Models. Account Org Soc 35: 676-688.

2. International Accounting Patterns, Culture, and Development (2011) Chapter 2, Classification of Accounting and Reporting Systems.

3. Oguri $\mathrm{T}$ (2005) Functions of accounting and accounting regulation: alternative perspectives based on Marxian economics. Critical perspectives on accounting 16: 77-94.

4. Crockett A (2000) Marrying the Micro- and Macro-Prudential Dimensions of Financial Stability. Basel, Switzerland.

5. Orlean A (1986) Mimétisme et anticipations rationnelles: une perspective Keynésienne. 52: 45-66.

6. Casta JF (1997) La politique comptable des societies. 2: 2276-2301.

7. Chiapello E (2003) Accounting and the birth of the notion of capitalism. Crit Perspect Account 18: 263-296.

8. Laux C, Leuz C (2009) The Crisis of Fair Value Accounting: Making Sense of the Recent Debate. Account Org Soc 34: 826-834.

9. Barth ME, Beaver WH, Landsman WR (1993) Structural analysis of SFAS 87 pension disclosures and their relation to share prices. Financ Anal J 49: 18-26.

10. Barth ME, Landsman WR (1995) Fundamental issues related to using fair value accounting for financial reporting. Accounting Horizons 9: 97-107.

11. Barth ME, Beaver WH, Landsman WR (1996) Value-relevance of banks fair value disclosures under SFAS No. 107. Account Rev 71: 513-537. 
12. Wolk HI, Dodd JL, Rozycki JJ (2007) Accounting Theory: Conceptual Issues in a Political and Economic Environment. $7^{\text {th }}$ Edition, Sage Publications.

13. Sterling RR (1975a) Relevant financial reporting in an age of price changes. J Accountancy 141: 42-51.

14. Sterling RR (1975b) Toward a science of accounting. Financial Analysts Journal 31: 28-36

15. Sterling RR (1975c) Professional schools of accounting: Some academic questions. In Bizzell AH, Larson KD (1975) Schools of Accountancy: A Look at the Issues. American Institute of Certified Public Accountants, New York, USA.

16. Stamp E (1981) Why Can Accounting Not Become a Science Like Physics?. ABACUS 17: 13-27.

17. Shubik M (2007) Accounting and its relationship to general equilibrium theory.

18. Gray SJ (1988) Towards a Theory of Cultural Influence on the Development of Accounting Systems Internationally. Abacus 24: 1-15.]

19. Gray SJ, Vint HM (1995) The Impact of Culture on Accounting Disclosures: Some International Evidence. Asia-Pac J Accounting 2: 33-43.

20. Harrison GL, McKinnon JL (1986) Culture and Accounting Change: A New Perspective on Corporate Reporting Regulation and Accounting Policy Formulation. Account Org Soc 11: 233-252.

21. Jensen MC, Meckling WH (1976) Theory of the firm: managerial behavior, agency costs and ownership structure. J Financ Econ 3: 305-360.

22. Coase RH (1960) The Problem of Social Cost. J Law Econ 3: 1-44.

23. Coase RH (1989) The Firm, the Law and the Market. 77: 223-231.

24. Chiapello E, Medjad K (2009) An unprecedented privatisation of mandatory standards-setting: The case of European accounting policy. Crit Perspect Account 20: 448-468.

25. Orlean A (1993) Analyse économique des conventions.

26. Watts RL (1974) Accounting objectives. working paper, University of Rochester, USA.

27. Watts RL, Zimmerman JL (1978) Towards a positive Theory of the Determination of Accounting Standards. The Accounting Review 53: 112-134.

28. Aglietta M (1998) L'avenir du capitalism. Note de la fondation SaintSimon, Paris.

29. Aglietta M, Reberioux A (2004) Du capitalisme financier au renouveau de la social-démocratie. Albin Michel, Paris.

30. Ijiri Y (1967) The Foundations of Accounting Measurement.

31. Ohlson J, Penman SH (1989) Financial statement analysis and the prediction of stock returns. J Accounting Econ 11: 295-329.

32. Ohlson J (1995) Earnings, book values and dividends in security valuation. Contemporary Accounting Research 11: 661-687.

33. Whalen CJ (2008) Post-Keynesian Institutionalism and the Anxious Society. In Batie S, Mercuro N (2008) Assessing the Evolution and Impact of Alternative Institutional Structures. Routledge, London.

34. Sunder S, Yamaji H (1999) The Japanese Style of Business Accounting. Quorum Press, Westport, CT.

35. IASB Advisory Panel (2008) Measuring and disclosing the fair value of financial instruments in markets that are no longer active.

36. Oguri T, Hara Y (1990) A Critical Examination of Accounting Regulation in Japan. Accounting, Auditing and Accountability Journal 3: 37-51.

37. Sunder S (2002) Knowing What Others Know: Common Knowledge, Accounting, and Capital Markets. Yale University, USA.

38. Shubik M (2011) A Note on Accounting and Economic Theory: Past, Present, and Future. Yale University, USA.

39. Watts RL, Zimmerman JL (1990) Positive Accounting Theory: a Ten Year Perspective. The Accounting Review 65: 131-156.

40. Ball R, Brown P (1968) An empirical evaluation of accounting income numbers. J accounting res 6: 159-178.
41. Ball R (1968) The economics of accounting policy choice. Mac Graw Hill.

42. Beaver WH (1996) Financial ratios as predictors of failure. J Accounting Res 4: 71-111.

43. Beaver WH, Engel EE (1996) Discretionary behavior with respect to allowances for loan losses and the behavior of security prices. J Accounting Econ 22: 177-206.

44. Ijiri Y (1989) Momentum Accounting and Triple-Entry Bookkeeping. Studies in Accounting Research, American Accounting Association, Sarasota FL.

45. Holthausen RW, Larcke DS, Sloan RG (1995) Annual bonus schemes and the manipulation of earnings. J Accounting Econ 19: 29-74.

46. Casta JF (2009) Théorie positive de la comptabilité. Encyclopédie comptabilité, contrôle, audit, Economica 1393-1402.

47. Kaplan RS, Roll R (1972) Investor evaluation of accounting information: some empirical evidence. J Bus 45: 225-257.

48. Posner AR (1974) Theories of Economic Regulation. the Bell Journal of Economics and Management Science 5: 335-358.

49. Minsky HP (1978) The financial instability hypothesis: a restatement.

50. Minsky HP (1980b) Capitalist financial processes and the instability of capitalism. J Eco 14: 505-523.

51. Minsky HP (1986) Stabilizing an Unstable Economy.

52. Minsky HP (1996) Uncertainty and the Institutional Structure of Capitalist Economies. J Eco 1-6.

53. Dupuy JP (1989) Convention et Common knowledge. Rev Econ 40: $361-400$.

54. Schelling TC (1980) The strategy of conflict. Harvard University Press, USA.

55. Lewis DK (1969) Convention: A Philosophical Study. Blackwell Publishers, USA.

56. Kothari SP (2001) Capital Markets Research in Accounting. J Accounting Econ 31: 105-231.

57. Keynes JM (1936) The General Theory of Employment, Interest and Money. Cambridge University Press, UK.

58. Sunder S (1997) Theory of Accounting and Control. South-Western College Pub.

59. Amblard M (2002) Comptabilité et conventions. L'Harmattan.

60. Amblard M (2004) Conventions et comptabilité: vers une approche sociologique du modèle. Comptabilité Contrôle Audit, 47-67.

61. Amblard M (2004) Conventions et modélisation comptable. 61-87.

62. Gomez DM, Anthony RG (1996) Amphibian and reptile abundance in riparian and upslope areas of five forest types in western Oregon. Northwest Sci 70: 109-119.

63. Gordon P (1992) Accounting Earnings Announcements, Institutional Investor Concentration, and Common Stock Returns J Accounting Res 30: $146-155$.

64. Minsky HP (1983) Money and Crisis in Schumpeter and Keynes.

65. Minsky HP (1993) Schumpeter and Finance. In Biasco S, Roncaglia A, Salvatti M (1992) Market and Institutions in Economic Development: Essays in Honor of Paulo Sylos Labini. 103-15.

66. Wolfson M, Kotz DM (2010) A Reconceptualization of Social Structure of Accumulation Theory. In McDonough T, Reich M, Kotz DM (2010) Contemporary Capitalism and Its Crises: Social Structure of Accumulation Theory for the Twenty First Century. Cambridge University Press, New York, USA.

67. McDonough $\mathrm{T}$ (1994) The construction of social structures of accumulation in US history. In Kotz DM, McDonough T, Reich M (1994) Social Structures of Accumulation: the Political Economy of Growth and Crisis. Cambridge University Press, 101-132.

68. Kotz DM, McDonough T, Reich M (1994) Social Structures of Accumulation: The Political Economy of Growth and Crisis. Cambridge University Press, UK.

69. Kotz DM, McDonough $T$ (2008) Global Neoliberalism and the Contemporary Social Structure of Accumulation. 
Citation: Yagoubi S (2014) Accounting Theories, Financialization Process and Neoliberalism. J Glob Econ 2: 116. doi:10.4172/2375-4389. 1000116

70. Wallace M, Brady D (2010) Globalization or Spatialization? The Worldwide Spatial Restructuring of the Labor Process. 121-144 In McDonough T, Reich M, Kotz DM (2010) Contemporary Capitalism and Its Crises: Social Structure of Accumulation Theory for the Twenty First Century. Cambridge University Press, New York, USA.

71. Cox R (1987) Production, Power and World Order. Columbia University Press, New York.

72. Castells M (2000) The Rise of the Network Society. Oxford: Blackwell, Cambridge, MA, USA.

73. Arnold PJ (2005) Disciplining Domestic Regulation: The World Trade Organization and the Market for Professional Services. Account Org Soc 30: $299-330$.

74. Kotz DM (2002) Globalization and Neoliberalism. In Rethinking Marxism 12: 64-79.

75. Boyer R (2007) Assessing the impact of fair value upon financial crisis Socio Econ Rev 5: 779-807.

76. Palley TI (2008) Financialization: What it is and Why it Matters.

77. Dumenil G, Dominique L (2001) Costs and Benefits of Neoliberalism. 8: 578-607.

78. Epstein G (2005) Financialization and the World Economy. Edward Elgar, Cheltenham and Northampton.
79. Epstein GA, Jayadev A (2005) The Rise of Rentier Incomes in OECD Countries: Financialization.

80. Arrighi G (2007) Adam Smith in Beijing. Verso, London.

81. Arnold PJ (2009a) Global Financial Crisis: The challenge to Accounting Research. Account Org Soc 34: 803-809.

82. Yagoubi S, Hamdaoui M (2013) Fair Value, Capital Accumulation and Financial Instability: A Macrodynamic Model. Int J Econ Financ 5: 116-130.

83. Cooper DJ, Sherer M J (1984) The value of corporate accounting reports: arguments for a political economy of accounting. Account Org Soc 9: 207-232.

84. Aglietta M (1979) Bond covenants and the choice of accounting techniques: the case of alternative depreciation methods. Working paper.

85. Harvey D (2005) A Brief History of Neoliberalism. Oxford University Press, USA.

86. Harvey D (2010) The enigma of capital. Oxford University Press, USA.

87. Kotz DM (2008) Contradictions of Economic Growth in the Neoliberal Era: Accumulation and Crisis in the Contemporary U.S. Economy. Review of Radical Political Economics 40: 174-188. 